\title{
Effectiveness of European Atlanto-Mediterranean MPAs: Do they accomplish the expected effects on populations, communities and ecosystems?
}

\author{
J.A. García-Charton ${ }^{a, *}$, A. Pérez-Ruzafa ${ }^{a}$, C. Marcos $^{a}$, J. Claudet ${ }^{b}$, \\ F. Badalamenti ${ }^{c}$, L. Benedetti-Cecchi ${ }^{d}$, J.M. Falcón ${ }^{e}$, M. Milazzo ${ }^{f}$, \\ P.J. Schembris, B. Stobart ${ }^{h}$, F. Vandeperre', A. Brito ${ }^{\mathrm{e}}$, R. Chemellof, \\ M. Dimech ${ }^{\mathrm{g}}$, P. Domenici ${ }^{j}$, I. Guala ${ }^{k}$, L. Le Diréach', E. Maggi ${ }^{d}$, S. Planes ${ }^{m}$
}

\footnotetext{
${ }^{a}$ Departamento de Ecología e Hidrología, Universidad de Murcia, Campus de Espinardo, 30100 Murcia, Spain ${ }^{\mathrm{b}}$ Laboratory of Zoology and Marine Biology, DiSTeBA - Department of Biological and Environmental Science and Technologies, University of Salento, Via Monteroni 73100 Lecce, Italy

'Istituto per l'Ambiente Marino Costiero, CNR, Laboratorio di Ecologia Marina, Via G. Da Verrazzano 17, 91014 Castellammare del Golfo, Italy

${ }^{\mathrm{d} D i p a r t i m e n t o}$ di Biologia, University of Pisa, Via Derna 1, 56126 Pisa, Italy

eDepartamento de Biología Animal, Facultad de Biología, Universidad de La Laguna, Avenida Astrofísico Francisco Sánchez S/N, Campus de Anchieta, 38206 La Laguna, Tenerife, Spain

${ }^{f}$ Dipartimento di Ecologia, Università degli Studi di Palermo, Via Archirafi 18, 90123 Palermo, Italy

${ }^{\text {g}}$ Department of Biology, Faculty of Science, University of Malta, Msida MSD 2080, Malta

${ }^{\mathrm{h}}$ Centro Oceanográfico de Baleares, Instituto Español de Oceanografía, Aptdo. 291, 07080 Palma de Mallorca, Spain

'Departamento de Oceanografia e Pescas, Universidade dos Açores, 9901-862 Horta, Portugal

${ }^{\mathrm{j}}$ Istituto per l'Ambiente Marino Costiero, CNR, Località Sa Mardini, 09072 Torregrande, Oristano, Italy

k International Marine Centre, Località Sa Mardini, 09072 Torregrande, Oristano, Italy

'GIS Posidonie, Centre d'Océanologie de Marseille, Parc Scientifique et Technologique de Luminy, case 901, 13288 Marseille Cedex 09, France

mUMR 5244 EPHE - CNRS - UPVD, Centre de Biologie et d'Écologie Tropicale et Méditerranéenne, Université de Perpignan, 52 Av. Paul Alduy, 66860 Perpignan Cedex, France
}

\section{KEYWORDS}

Marine conservation;

Marine protected

areas;

Marine reserve;

Coastal populations

and communities;

Coastal habitats;

\begin{abstract}
Summary
The success of MPAs in conserving fishing resources and protecting marine biodiversity relies strongly on how well they meet their planned (or implicit) management goals. From a review of empirical studies aiming at assessing the ecological effects of Mediterranean and Macaronesian MPAs, we conclude that establishing an MPA is successful for (i) increasing the abundance/biomass, (ii) increasing the proportion of larger/older individuals, and (iii) enhancing the fecundity of commercially harvested populations; also, MPAs demonstrated to be
\end{abstract}

*Corresponding author. Tel.: +34968398184.

E-mail address: jcharton@um.es (J.A. García-Charton). 
Meta-analysis; Mediterranean; Macaronesia effective for (iv) augmenting local fishery yields through biomass exportation from the protected area, and ( $v$ ) inducing shifts in fish assemblage structure by increasing the dominance of large predator species. However, the attraction for tourism and diving due to ecological benefits of protection can cause damages likely to reverse some of the MPA effects. Other expected effects are more subject to uncertainty, and hence need more research, such as (vi) causing density-dependent changes in life history traits and (vii) protecting the recruitment of commercially important species, (viii) protecting marine biodiversity (including genetic diversity), (ix) causing ecosystem-wide effects such as trophic cascades, and $(x)$ increasing community and ecosystem stability, thus promoting resilience and faster recovery from disturbance. Meta-analysis of data arising from these case studies are used to establish the overall effect of MPAs, and its relationship to MPA features, such as size of no-take area or time since protection. Based on the review and the metaanalyses, specific recommendations are provided for MPA management, regarding the establishment of goals and objectives, site selection, MPA design and zoning, planning, and monitoring. Finally, a series of recommendations for MPA research are offered to drive future research in MPA issues in the Mediterranean and Macaronesia. (c) 2008 Elsevier $\mathrm{GmbH}$. All rights reserved.

\section{Introduction}

Coastal ecosystems are among the most productive of the planet, and play a major role in coastal fisheries as nursery and feeding grounds (Martinez et al., 2007). Coastal ecosystems are particularly vulnerable to human actions causing the erosion of marine biodiversity (Halpern et al., 2008; Jackson, 2008), and the Mediterranean Sea is no exception (RAC/SPA, 2003; European Environment Agency, 2006). There is a general consensus on the role of over-fishing as the primary anthropogenic disturbance causing local extinctions (Jackson et al., 2001). Albeit oceans have lost much of their fish biomass and megafauna due to hunting, other causes can also explain marine species losses (Dulvy et al., 2003). Key coastal habitats are being lost globally at rates 2-10 times faster than those in tropical forests (Balmford et al., 2005; Lotze et al., 2006). Other sources of erosion of marine biodiversity are pollution (European Environment Agency, 2006), invasion by alien species (Gollasch, 2006) and catastrophic shifts induced by global warming (Harley et al., 2006). Importantly, however, over-fishing is likely to be the main facilitating factor for the synergistic effects of all other sources of erosion of marine biodiversity (Jackson et al., 2001). Recently, Worm et al. (2006) stated that unless corrective measures are implemented with urgency, stocks of fish species of commercial interest will have completely collapsed by 2050 , causing upheavals in the global ecosystem through the loss of particular functions played by key species (Cury et al., 2008; but see Longhurst, 2007).

The solutions proposed by managers to address this near-insurmountable problem are multiple
(Pauly, 2005; Pauly et al., 2002) and rely mainly on (1) reducing fishing capacity through traditional fisheries management measures (e.g. quotas, reducing the fishing effort, regulating fishing equipment) and (2) developing the internationally advocated ecosystem-based fisheries management (EBFM) approach, for which the overall ecosystem complexity is perceived as critical for sustainable use of marine resources (Cury, 2004; Jennings, 2004). The first set of strategies have not provided the anticipated effects except in a few cases worldwide, the causes for that being rooted in multiple factors (Beddington et al., 2007; Dankel et al., 2008; Daw \& Gray, 2005; Hilborn, 2004; Mace, 2004). For its part, EBFM is still exploring practical ways of effective implementation (Francis et al., 2007; Longhurst, 2006; Misund \& Skjoldal, 2005; Sherman et al., 2005; Smith et al., 2007).

Marine protected areas (MPAs) have been advocated as a major tool for both protection of marine biodiversity and conservation of marine resources (Lubchenco et al., 2003; Pauly, 2005; Roberts et al., 2005). Marine spatial planning of human activities through the setting up of MPAs is viewed as a tool for applying an EBFM (Agardi, 2005; Browman \& Stergiou, 2004; Gilliland \& Laffoley, 2008; Pauly et al., 2002; Sissenwine \& Murawski, 2004). In the Mediterranean, the number of MPAs has been growing since the first establishment of Port-Cros national park in 1963 (Badalamenti et al., 2000; Francour et al., 2001; Fraschetti et al. 2005), and a conservative estimate today would be of some 94 MPAs (Abdulla et al., in press), which however protect less than $1 \%$ of the Mediterranean coastal area. These figures, which are representative of the situation worldwide, make it very 
difficult to reach the international targets to which the EU has committed itself, for example the 2012 target adopted in the World Summit on Sustainable Development (WSSD) (Wood et al., 2008).

The anticipated ecological effects of MPAs are multiple and influence populations, communities and ecosystems (Allison et al., 1998; Bohnsack, 1996; Dugan \& Davis, 1993; García-Charton \& Pérez-Ruzafa, 1999; García-Charton et al., 2000; Halpern, 2003; Jones et al., 1992; Palumbi, 2001; Pelletier et al., 2005; Pinnegar et al., 2000; Plan Development Team, 1990; Planes et al., 2000; Roberts \& Polunin, 1991; Rowley, 1994; Russ, 2002; Sánchez-Lizaso et al., 2000; Ward et al., 2001). However, not all these expected effects have been empirically demonstrated, or, in some cases, even assessed (Hilborn et al., 2004; Pelletier et al., 2005, 2008; Sale et al., 2005); moreover, the magnitude of the response to protection may vary based on geographic location, the characteristics of the species, the type of communities within the MPA, and the design features of the MPA (BlythSkyrme et al., 2006; Claudet et al., 2008).

Within this context, the European Commission funded a 3-year (2005-2008) research programme called "European Marine Protected Areas as tools for FISHeries management and conservation" (EMPAFISH) to: (i) investigate the potential of different regimes of MPAs in southern Europe as measures to protect sensitive and endangered species, habitats and ecosystems from the negative effects of fishing; (ii) develop quantitative methods for assessing the effects of MPAs; and (iii) provide the EU with a set of integrated measures and policy proposals for the implementation of MPAs as fisheries and ecosystem management tools. The work carried out during the project was mainly based on existing data on ecological, fisheries and socio-economic aspects of already established and mostly well-studied MPAs (Figure 1). Among other tasks, the EMPAFISH partners reviewed the ecological effects of MPAs and conducted meta-analyses on the compiled database. The aims of the present paper are to (i) review the research made to date on the ecological effects of MPAs in the Mediterranean and in the Macaronesian archipelagos and (ii) present the results of the meta-analyses of the EMPAFISH case studies. Ultimately, the goal is to provide an answer to the question: "Do the Mediterranean and Macaronesian MPAs accomplish their expected ecological effects?" and based on the above results, to provide recommendations for MPA management and research in this geographical context.

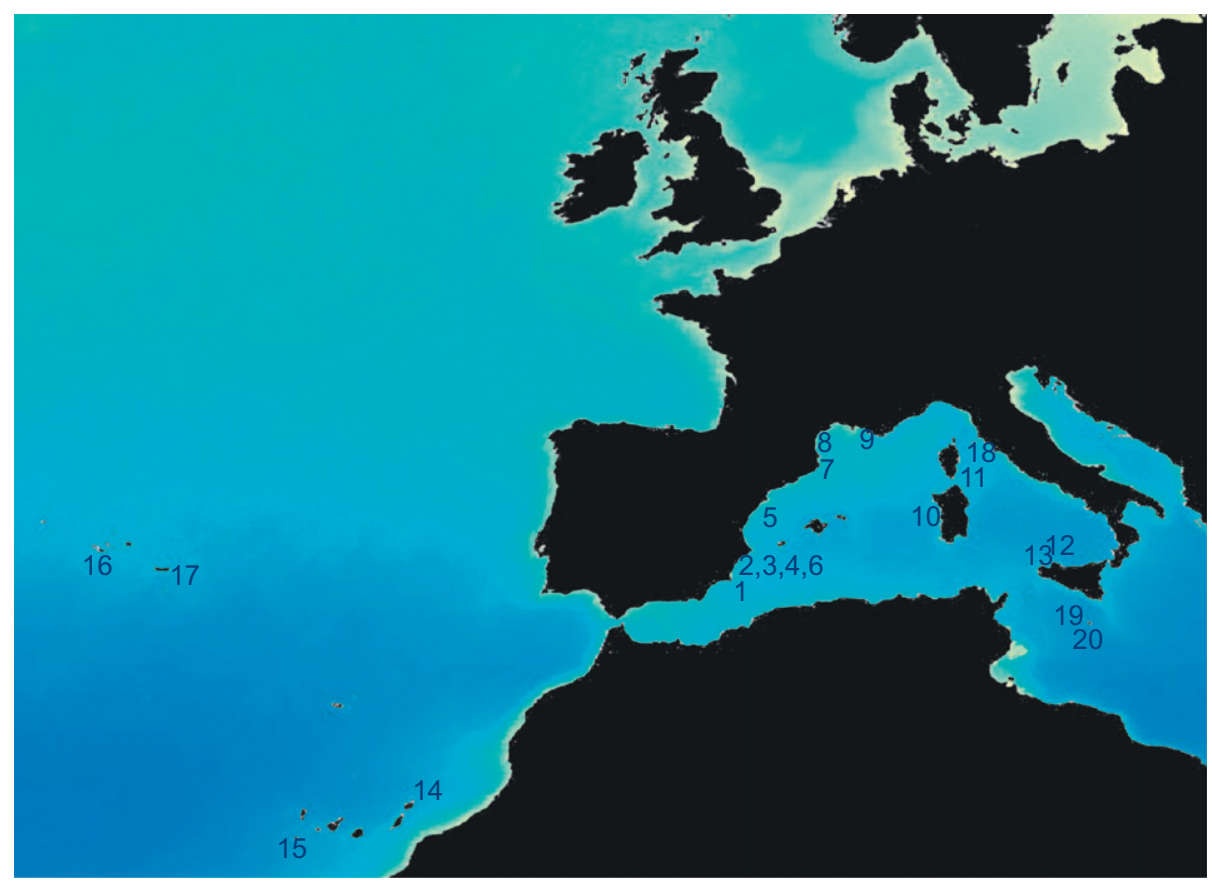

Figure 1. Location of MPAs included as case studies in the EMPAFISH project. (1) Cabo de Palos - Islas Hormigas; (2) Tabarca; (3) San Antonio; (4) Serra Gelada - Benidorm islets; (5) Columbretes is.; (6) Anti-trawling zones (SE Spain); (7) Medes Is.; (8) Cerbère-Banyuls; (9) Parc marin de la Côte Bleue; (10): Sinis - Mal di Ventre; (11) Bouches de Bonifacio; (12) Ustica is.; (13) Gulf of Castellammare; (14) La Graciosa - Islotes del norte de Lanzarote; (15) La Restinga - Mar de las Calmas; (16) Monte da Guia - Faial; (17) Formigas islets - Dollabarat bank; (18) Tuscany archipelago; (19) 25-NM FMZ around Malta; (20) Rdum Majjiesa - Ras Ir-Raheb. 
Table 1. Expected ecological effects of MPAs (modified from Ward et al., 2001; Pelletier et al., 2005).

\begin{tabular}{|c|c|}
\hline Population level & $\begin{array}{l}\text { 1. Protecting critical spawning stock } \\
\text { biomass of species from fishery- } \\
\text { related depletion } \\
\text { 2. Rehabilitating population } \\
\text { structure } \\
\text { 3. Increasing fecundity and } \\
\text { production of eggs and larvae } \\
\text { 4. Density-dependent changes in lif } \\
\text { history traits and parasitism } \\
\text { 5. Exportation of biomass } \\
\text { 6. Protection of recruitment }\end{array}$ \\
\hline $\begin{array}{l}\text { Community and } \\
\text { habitat level }\end{array}$ & $\begin{array}{l}\text { 7. Restoration of/changes in } \\
\text { assemblage structure } \\
\text { 8. Protection of biodiversity } \\
\text { 9. Indirect effects on algae and } \\
\text { invertebrates } \\
\text { 10. Increasing ecosystem stability } \\
\text { and resilience } \\
\text { 11. Detrimental effects due to non- } \\
\text { exploitative uses }\end{array}$ \\
\hline
\end{tabular}

\section{Part A - Ecological effects of Atlanto- Mediterranean MPAs: a literature review}

Ward et al. (2001) synthesised the literature on MPAs and listed all the (i) ecological and fisheriesrelated, (ii) economic, and (iii) social effects that can be expected from the implementation of an MPA (see also Pelletier et al., 2005). Ecological effects were distinguished by these authors according to those acting on populations, communities, ecosystems, and habitats (Table 1). Many studies have been made to date to assess such ecological effects in Atlantic and Mediterranean MPAs (Planes et al., 2008). This set of evidence (either positive, neutral or negative) constitutes a strong body of data which can be used to assess the pertinence of MPAs as a tool for fisheries management and ecosystem conservation. In this section we review these results.

\section{Expected ecological effects at population level}

\section{Protecting critical spawning stock biomass of species from fishery-related depletion}

Most studies on Mediterranean and Macaronesian MPAs made to date showed higher abundance and/ or biomass within MPAs compared to unprotected sites, either for target species or for fish assemblages as a whole. A majority of studies focused on fish populations (e.g. Bell, 1983; Claudet et al., 2006a; García-Charton et al., 2004; García-Charton \& Planes, 2002; García-Rubies \& Zabala, 1990; Guidetti et al., 2005; Harmelin et al., 1995; Harmelin-Vivien et al., 2008; La Mesa \& Vacchi, 1999; Macpherson et al., 2002; Reñones et al., 2001). As further examples, García-Charton et al. (2007) have measured an important increase in abundance and biomass of target species in Cabo de Palos - Islas Hormigas marine reserve (Murcia, Spain) after 11 years of protection (Figure 2). For its part, in La Graciosa marine reserve (Lanzarote, Canary archipelago, Spain), protection measures have contributed to the increase and/or the maintenance of the populations of certain heavily exploited fishes, such as Sparisoma cretense, Serranus atricauda and, to a lesser extent, Mycteroperca fusca (Falcón et al., 2007b) (Figure 3). Dimech et al. (in press) attributed differences in the demersal assemblages of the Maltese outer continental shelf inside and outside the 25-nautical mile Fisheries Management Zone (FMZ) (an MPA established for fisheries conservation that has been in existence in one form or another since 1971; Camilleri, 2003) around the Maltese Islands to different fishing pressures inside (where fishing is strictly regulated) and outside (where there are no restrictions on fishing) the FMZ. These authors found quantitative differences between the two continental shelf assemblages with species groups sensitive to trawling, such as elasmobranchs (for example, Scyliorhinus canicula and Raja clavata), being very common inside and practically absent outside the 25 NM FMZ.

Other harvested populations may benefit from protection measures. For example, Goñi et al. (2001) showed that, depending on the season, densities of spiny lobster (Palinurus elephas) were 6-20 times greater within the Columbretes marine reserve (Spain) than in comparable fished areas. Similarly, Follesa et al. (2008) found a progressive percentage increase of $P$. elephas biomass values both inside a re-stocking area in western Sardinia and in surrounding zones once the protection measures were implemented. This was also the case with the giant limpet (Patella ferruginea), once common in the Mediterranean, but which has been driven to near extinction, mostly by human collection (Laborel-Deguen \& Laborel, 1991; Scotti \& Chemello, 2000). Remnant populations occur mostly on islands, including in Capraia Island (Tuscany Archipelago, Italy), where comparisons of the abundances of these populations inside and outside marine reserves (Benedetti-Cecchi et al. unpublished data) show the importance of MPAs in sustaining viable populations of this endangered 


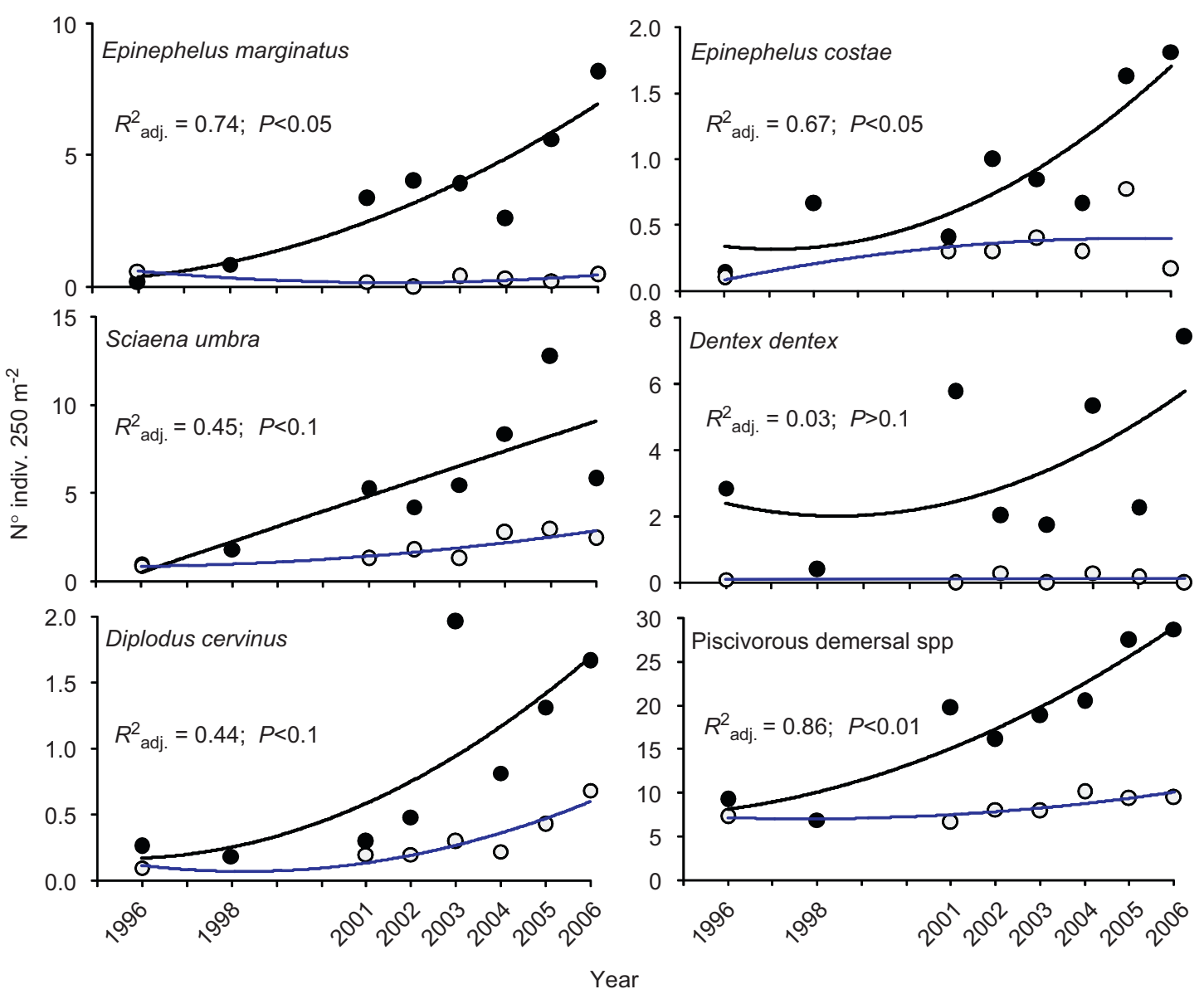

Figure 2. Mean abundance against time of some large predatory species, and considering all the piscivouros species together, in the Cabo de Palos - Islas Hormigas marine reserve $(\bullet)$, and in an unprotected control locality (Águilas) $(\bigcirc)$ in the coast of Murcia (SE Spain) after the establishment of protection measures in 1995 (from García-Charton et al., 2007); 2nd-order polynomial regressions, and adjusted $R^{2}$ and $P$-value of regressions for Cabo de Palos data are also shown.

species (Figure 4). Analogous results have been obtained for the same species by Meier (2003) in Bouches de Bonifacio marine park (Corsica, France). Also, in Cerbère-Banyuls natural marine reserve (France) Jacquet (1999) found larger individuals of Mytilus galloprovincialis within the protected area than in neighbouring sites.

As a result of halting human harvesting on echinoderm species, the density of edible sea urchins (Paracentrotus lividus) was three times higher within the Cerbère-Banyuls natural marine reserve, and the average test diameter was greater (Lecchini et al., 2002). Similar results were obtained in Ustica marine reserve (Italy) (Gianguzza et al., 2006) and in the Capo Caccia e Isola Piana marine reserve (Sardinia, Italy) (Pais et al., 2007). Guidetti et al. (2004) provided evidence that intense harvesting of $P$. lividus in southern Apulia (SE Italy) may cause reduction in average size and biomass of this echinoid because of the selective harvesting of the largest individuals; however, densities of
$P$. lividus in fished and control areas did not change. In another study on Miramare MPA (Italy), Guidetti et al. (2005) failed to find an effect of protection on sea urchins. However, compared to most other Mediterranean MPAs which consist predominantly of rocky bottoms, Miramare marine reserve is a very particular case since it consists of sandy bottoms and coastal defence works (breakwaters), and predatory fishes could primarily feed upon other invertebrates associated with muddy-sandy substrates in the vicinity of the artificial structures, in contrast to natural rocky habitats where they are known to prey upon sea urchins.

Other studies carried out in the Mediterranean give results contrary to expectations, and sometimes conflicting results are obtained by different workers in the same MPAs. For example, Dufour et al. (1995) failed to find the reserve effect described 12 years before by Bell (1983) in CerbèreBanyuls natural marine reserve. Similarly, Palmeri (2004) was not able to measure a significant effect 


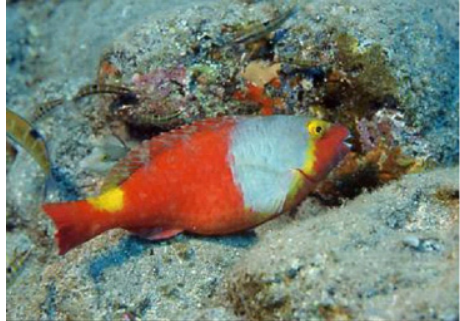

Sparisoma cretense $\left(^{*}\right)$

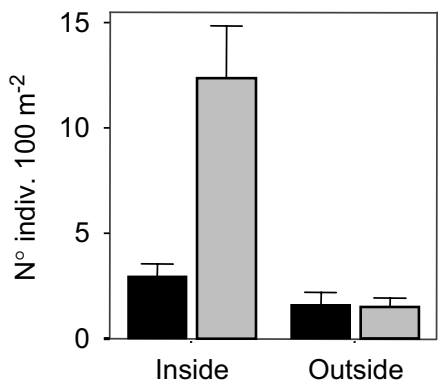

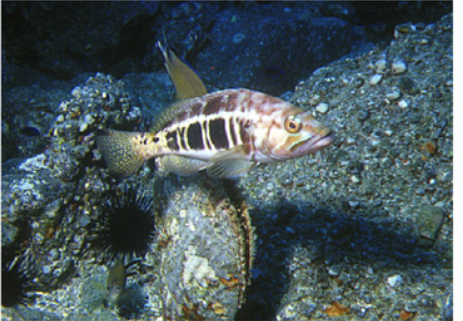

Serranus atricauda $\left(^{* *}\right)$

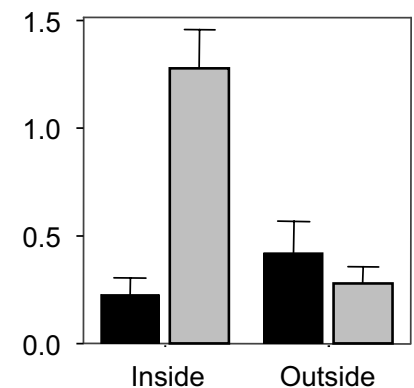

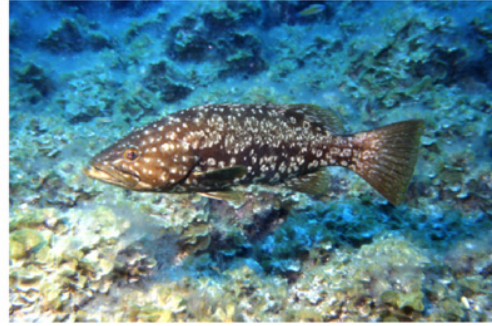

Mycteroperca fusca (ns)

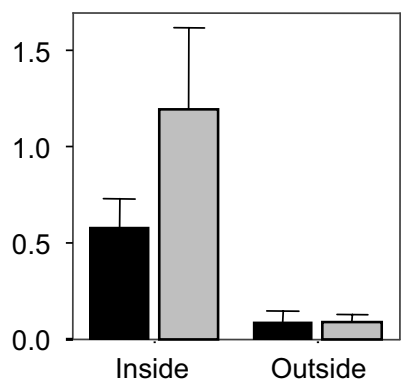

Figure 3. Before-after variation of the mean abundance ( \pm standard error) of three selected individual species inside and outside La Graciosa marine reserve (Canary Islands, Spain) (from Falcón et al., 2007b). Statistical significance of the interaction between temporal and spatial factors is indicated for each species.

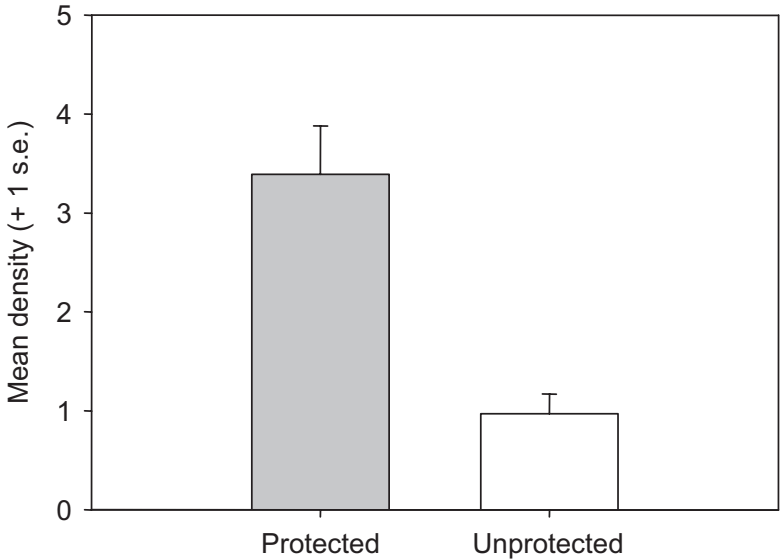

Figure 4. Difference in mean abundance (no. indiv. $\mathrm{m}^{-2}$ ) ( \pm standard error of the mean, s.e.) of $P$. ferruginea inside and outside MPAs of Capraia Island (Tuscany Archipelago) over several years $(P<0.05)$ (data of Benedetti-Cecchi et al. from different projects, including EMPAFISH).

of protection on fish assemblages in Ustica reserve (Sicily, Italy) despite a positive effect found previously in the same locality by La Mesa and Vacchi (1999). Along the same lines, Tunesi et al. (2006) did not detect a clear reserve effect on fish fauna in 'Cinque Terre' MPA (Ligurian Sea, Italy). Some of these controversial results could be linked to the MPA not having been in existence for a sufficiently long time to allow fish populations time to recover (García-Charton et al., 2004). For other studies, it may be problems with sampling design; studies may need to be made at broader temporal and spatial scales to determine with confidence whether the MPA had actually been effective in enhancing fish abundance (Fraschetti et al., 2002; García-Charton \& Pérez-Ruzafa, 1999; García-Charton et al., 2000; Guidetti, 2002).

Alternatively, in some cases these equivocal responses of protected populations could be a masking effect of habitat structure and depth, as both environmental factors exert a great influence on fish assemblages (García-Charton et al., 2000, 2004). As an illustration of this, García-Charton and Planes (2002) effectively detected a significant reserve effect on ichtyofauna at Cerbère-Banyuls natural marine reserve, thus corroborating the result of Bell (1983) (and contrary to Dufour et al., 1995); a distinct analysis of the data of García-Charton and Planes (2002) at a larger spatial scale using multivariate regression trees (Claudet et al. unpublished work) confirms that the effects of protection are more evident at shallow depths $(<10 \mathrm{~m})$, probably as a consequence of a recolonisation of shallow habitats in protected sites, while in deeper sites habitat structure is more important in explaining the observed differences. Therefore, these and other environmental factors (e.g. wind exposure) may enhance or reduce the protection effects in any MPA.

As patterns of recovery of target fish are also related to MPA management policies, a further cause of responses of target populations, which are contrary to expectations, is insufficient surveillance 
(Guidetti et al., 2008). If enforcement is lax, this will lower the perceived effectiveness of management plans, will increase the lack of compliance with restrictions, and will likely lead to the conclusion that marine reserves are ineffective.

An additional issue needs to be addressed, which is the effects of MPAs on fish density and biomass at regional scales. The positive effects of MPAs on fish populations are likely to involve two mechanisms: one is the positive effect of protection on fish stocks discussed so far; the other involves a redistribution effect, whereby MPAs would attract fish from other areas by providing a safer environ-

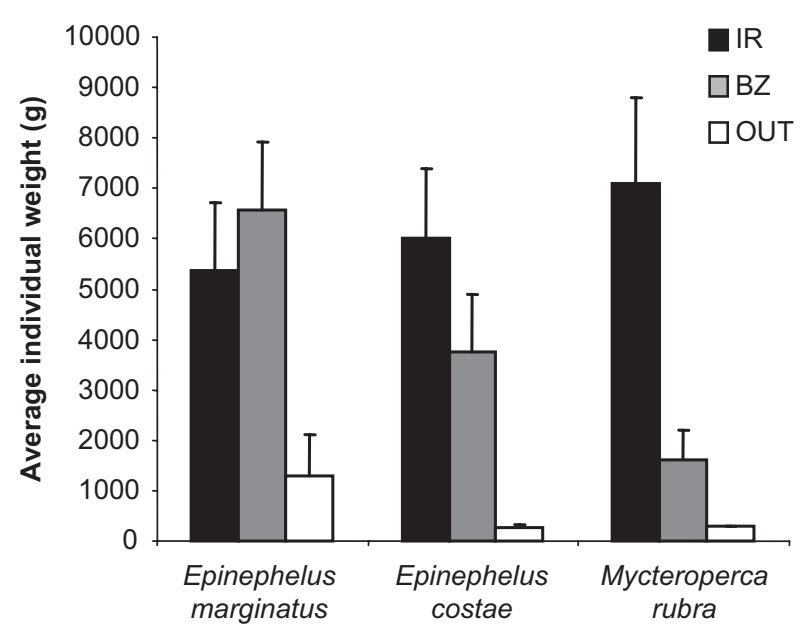

Figure 5. Differences in mean fish weight (g) for visually censused individuals of Epinephelus marginatus, $E$. costae and Mycteroperca rubra among levels of protection in Cabo de Palos - Islas Hormigas marine reserve eight years after the establishment of protection measures (IR: integral reserve or no-take area; BZ: buffer zone; OUT: fished areas) [all differences are significant at $P<0.05$ ] (modified from Harmelin-Vivien et al., 2007).
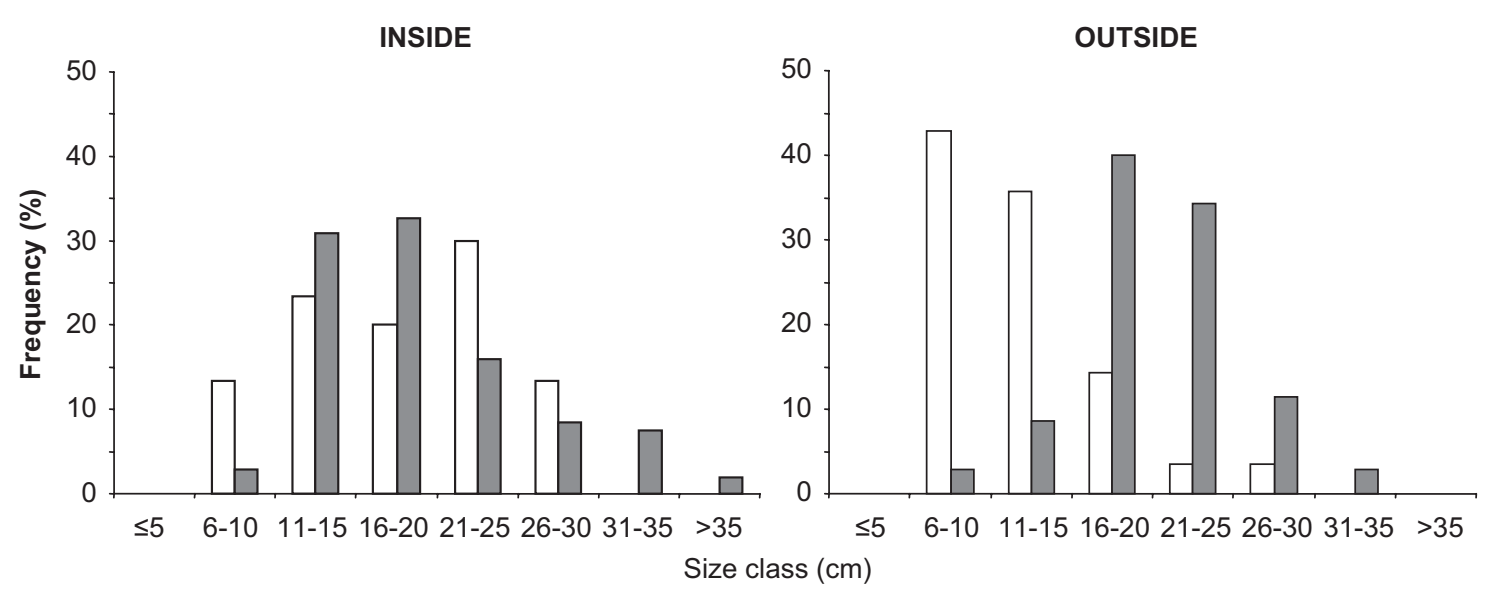

Figure 6. Comparison of the size structure (size classes in $\mathrm{cm}$ ) of Serranus atricauda inside and outside La Graciosa marine reserve, from one year before (white bars) to 10 years after (grey bars) the establishment of protection measures in 1995 (modified from Brito et al., 2006a). ment. These are two non-mutually exclusive mechanisms through which protection may operate, but positive effects of MPAs on regional fish abundances can only be expected if redistribution effects are negligible. Future studies on MPAs should therefore be designed to ensure comparison of spatial patterns in fish abundance and biomass from unprotected sites in geographical areas with MPA networks and similar, unprotected sites, in geographical areas far from MPAs. This approach will help to evaluate the results of large-scale marine bioregional spatial planning and management (Gilliland \& Laffoley, 2008; McGinnis, 2006).

\section{Rehabilitating population structure}

Because fishing activities exert a pressure mainly on larger/older individuals of commercial species, MPAs are expected to allow recovery of the population structure of these species. For instance, Harmelin-Vivien et al. (2007) observed in several Mediterranean MPAs that mean fish size of several species of groupers (Epinephelus marginatus, E. costae and Mycteroperca rubra) decreased from no-take zones to fished areas, and are generally intermediate in the buffer areas (for example, in Cabo de Palos - Islas Hormigas marine reserve; Figure 5). Cases where larger individuals were recorded in the buffer zones than in no-take areas are probably due to the more complex habitat in the former zones than in no-take areas for these species; for example, in Cabrera Archipelago national park (Balearic Islands, Spain), no-take areas are restricted to bays and harbour a higher number of small-sized individuals, as observed also by Reñones et al. (1999). Serranus atricauda and Sparisoma cretense populations changed their size structure both inside and outside protected areas 
after the formation of La Graciosa and La Restinga marine reserves (Canary Islands) (Brito et al., 2006a, 2006b) (Figure 6). The same trend was observed for spiny lobsters in the Columbretes marine reserve (Goñi et al., 2006). Dimech et al. (in press) found that elasmobranches were larger in size inside the Maltese FMZ, while the outer shelf region outside the FMZ had half the biomass and abundance of demersal species than inside the FMZ.

\section{Density-dependent changes in life history traits and in parasitism}

Since abundance, mean size and age of targeted populations increase within MPAs, density-dependent changes in life history traits are also expected to occur within MPAs (Sánchez-Lizaso et al., 2000; Ziegler et al., 2007). Some of these changes may even counteract other anticipated effects of protection (Gårdmark et al., 2005). However, the few studies made to date in the Mediterranean which compare such features of marine organisms in protected and exploited areas provide unclear evidence for density-dependent responses. Growth rate of juveniles of three Diplodus species did not show differences between fished and unfished areas (Planes et al., 1998). Post-spawners of Diplodus sargus were better conditioned within the rocky areas of the Cerbère-Banyuls natural marine reserve than in adjacent unprotected rocky areas (Lloret \& Planes, 2003); however, the authors did not find any significant effect of protection on feeding or reproductive potential. It has been repeatedly observed that natural mortality is higher within MPAs, but this is rather a result of increased predation on juveniles than reduction in fitness due to intra-specific competition (Macpherson et al., 1997, 2000; Planes et al., 1998, 2000; Sánchez-Lizaso et al., 2000).

Reproductive traits may also be affected by changes in the density of targeted populations, usually through an increase of size and/or age of sex reversal of hermaphroditic populations (Molloy et al., 2008). For example, females of Diplodus sargus (a protandric species) were present in two different age distributions inside and outside the Cerbère-Banyuls Natural Marine Reserve with younger females outside, suggesting plasticity in the age of sexual inversion in the case of an exploited population (Lenfant, 2003). A deficit of females of Diplodus sargus in exploited sites was observed within Cabo de Palos - Islas Hormigas MPA (González-Wangüemert, 2004), where the proportion of females and hermaphrodite individuals was higher within the MPA as a consequence of a greater mean size due to the reduced fishing pressure.

A further effect of MPAs on reproductive potential is to promote the occurrence of spawning aggregations as a result of increased density and size (Sánchez-Lizaso et al., 2000), as observed for E. marginatus in the Medes Islands (Zabala et al., 1997), Cerbère-Banyuls, Port-Cros and Lavezzi Islands marine reserves (Bodilis et al., 2003; Louisy \& Culioli, 1999). In Cabo de Palos - Islas Homigas, dominant males of several grouper species performing courtship activities and aggressive displays were recurrently observed (J.A. García-Charton, pers. observ.). The increase in density and size of fishes inside marine reserves can also facilitate the spread of certain types of directly transmitted parasitic diseases (Sasal, 2003; Sasal et al., 1996; Sasal et al., 1997).

The key issue that needs to be elucidated for understanding the importance of crowding in fish population as a response to protection measures is how long it takes, and to what extent the habitat within MPAs becomes saturated (i.e. reaches its carrying capacity to provide resources, such as food or refuge, to fish species) (Sánchez-Lizaso et al., 2000). Even if first effects on fish densities and individual fish sizes can be rapid (Claudet et al., 2006b; Halpern \& Warner, 2003), recent studies have highlighted that the length of time to full recovery of fish assemblages within an MPA may be considerable (several decades) (Claudet et al., 2008; McClanahan et al., 2008; Micheli et al., 2004; Russ \& Alcala, 2004). This is in agreement with historical studies and anecdotal evidence on the historical status of marine populations, which appear to have been much higher in the past than at present (Jackson et al., 2001; Knowlton \& Jackson, 2008; Pauly, 1995; Pinnegar \& Engelhard, 2008).

Ultimately, the effects of MPAs can reverse the causes of evolutionary shifts on life history traits due to the selective mortality of commercially exploited fish species induced by fishing (Jørgensen et al., 2007; Kuparinen \& Merilä, 2007), as predicted through eco-genetic modelling (e.g. Dunlop et al., 2007), and confirmed by empirical studies (e.g. Swain et al., 2007; Walsh et al., 2006).

\section{Increasing fecundity and production of eggs and larvae}

By increasing abundance and age of targeted organisms, MPAs are expected to enhance the fecundity of marine populations, thus boosting the production of eggs and larvae (Berkeley et al., 2004; Birkeland \& Dayton, 2005; Gerber \& Heppell, 2004; Plan Development Team, 1990; 
Planes et al., 2000). Nevertheless, few empirical studies have measured this response of protected stocks in the Mediterranean or elsewhere. As a result of changes in abundance in the spiny lobster population, the spawning potential in the Columbretes MPA may have increased 6-20 times after a 10-year fishing ban (Goñi et al., 2003). The effects of changes in age/size structure in the protected population was minimised by the short period since protection measures were implemented as compared to the life span of spiny lobster (Goñi et al., 2003), although the importance of greater male size for the success of breeding pairs can be emphasised.

\section{Exportation of biomass and connectivity}

MPAs are expected to enhance local fishery yields through biomass exportation to surrounding nonprotected areas, as a result of increased densities and fecundity of exploited species inside MPAs (Plan Development Team, 1990). This can arise through two main mechanisms: net emigration of adult and juvenile fishes ("spill-over effect"); and, export, of pelagic eggs and larvae from restored spawning stocks inside the MPA (Alcala et al., 2005; Gell \& Roberts, 2003; Roberts \& Polunin, 1991; Rowley, 1994). On the other hand, studies on the demographic connectivity of marine populations are crucial to fully understand the functioning of MPAs in terms of inter-element distance in an MPA network (Palumbi, 2003; Sale et al., 2005), and therefore for the correct design of marine reserves (Laurel \& Bradbury, 2006).

The study of biomass export from MPAs to neighbouring areas can be done by analysing longterm data (Roberts et al., 2001; Russ \& Alcala, 1996, 2004), by measuring gradients of biomass through the marine reserve border (Abesamis et al., 2006; Chapman \& Kramer, 1999; KaundaArara \& Rose, 2004; Rakitin \& Kramer, 1996), or directly by performing tagging and acoustic tracking studies (e.g. Attwood \& Bennett, 1994; Zeller \& Russ, 1998).

In the Mediterranean, several authors have surveyed biomass export by measuring gradients of biomass across MPA limits, and in general they reach the conclusion that spill-over effectively occurs, although its spatial extent is moderate (hundreds of metres). A significant non-linear decline of CPUE of lobster ( $P$. elephas) with distance from the centre of the no-take zone, with a depression at the boundary followed by a plateau was observed at the Columbretes MPA (Goñi et al., 2006). This depression was caused by local depletion associated with concentration of fishing effort at the reserve boundary, while the plateau suggests that lobster export from the reserve is sufficient to maintain stable catch rates up to $1500 \mathrm{~m}$ from the boundary. Analysis of recaptures of lobsters tagged and released inside the reserve indicated that the density gradient was caused by lobsters emigrating from the reserve (Goñi et al., 2006). Similar results using lobster mark-recapture data were obtained in western Sardinia (Follesa et al., 2007), and in Torre Guaceto MPA (Italy) for Diplodus spp. (Guidetti, 2006b).

Recently, the EC research project BIOMEX (http://biomex.univ-perp.fr; BIOMEX, 2005) assessed the export of fish biomass from MPAs to neighbouring areas in a set of six littoral MPAs in the western Mediterranean, using several complementary sampling methods. Using an underwater visual census (UVC) technique, Harmelin-Vivien et al. (2008) observed significant negative gradients in mean fish biomass in all the reserves studied after the effect of habitat had been removed, whereas negative gradients in abundance were less conspicuous. A closer inspection of the shape of these gradients suggest two main patterns of biomass gradients, with a sharp decrease at the no-take area/buffer zone boundary or at the buffer zone/ fished area boundary, probably as a consequence of the strong fishing pressure exerted along the MPA borders. Using baited underwater video (Stobart et al., 2007), results similar to those obtained by UVC were observed for a few fish species targeted by fisheries (BIOMEX, 2005). Surveys of the distribution of eggs and larvae of selected target species revealed high densities of eggs and larvae inside the MPAs in comparison with adjacent areas and decreasing gradients away from the core of the MPAs (BIOMEX, 2005). Besides protection, the distribution of eggs and larvae depends greatly on hydrology and current patterns, on the inter- and intra-species-specific differences in larvae behaviour, and on habitat features and the distribution of adults (BIOMEX, 2005). Analyses of the spatial distribution of fishing effort, of fishery production and of revenues showed evidence of effort concentration and highest fishery production near the no-take zone boundaries of all MPAs (Goñi et al., 2008; Stelzenmüller et al., 2007). In most cases, a significant decreasing slope of effort intensity and CPUE from the core of the MPA was found (Goñi et al., 2008). In Atlantic case studies, the abundance/ biomass of three exploited fish species (Sparisoma cretense, Serranus atricauda and Mycteroperca fusca) in La Restinga marine reserve responded differently to the protection measures, by increasing the abundance/biomass inside the no-take zone as compared to the other zones of the reserve (Falcón et al., 2007a). A gradient in 
abundance/biomass of these species throughout the zones with different protection levels within the MPA was progressively taking place after the implementation of protection measures, which can be considered as evidence of spill-over from the no-take zone to the neighbouring areas.

The few studies on the movement patterns and homing of fish species by telemetry made to date within the geographical scope of this article, in general show strong site fidelity of adult and young groupers (Astruch et al., 2007; Lembo et al. 2002). Similar results where obtained for parrotfish (Sparisoma cretense) in Azorean waters, limiting this species' potential to benefit the fisheries through spill-over to areas close to the reserve boundaries (Afonso et al., 2008).

Connectivity between marine areas for a given species can be studied by a variety of recently developed techniques (Palumbi et al., 2003), such as remote sensing, marine circulation modelling, and tagging - including external (natural or artificial), chemical (trace elements or stable isotopes in otholiths) and genetic tags. Nevertheless, studies on connectivity are still scarce, in particular in the Mediterranean and Macaronesian context. González-Wangüemert et al. (2004) showed by means of electrophoretic data that the interchange of individuals between close populations of the white seabream (Diplodus sargus) in the western Mediterranean probably occurs as a response to complex paths through oceanographic currents. At higher spatial scales, however, the existence of exclusive alleles in each region accounted for most of the genetic distances found (Pérez-Ruzafa et al., 2006).

The use of otoliths to characterise local fish populations has been also limited; for instance, Gillanders et al. (2001) showed little variation in otolith chemistry of two-banded bream (Diplodus vulgaris) between locations along the south-west Mediterranean coast of the Iberian Peninsula. For their part, Mérigot et al. (2007) found significant differences in otolith shape in the common sole (Solea solea) according to both fish size and the type of environment in which the fish live (i.e. coastal lagoons versus marine sites), but also between sites belonging to the same type.

\section{Protection of recruitment}

MPAs can affect recruitment of marine populations by protecting both spawner abundances (see section 'Increasing fecundity and production of eggs and larvae' above), and nursery habitats for settlers and recruits (Planes et al., 2000). Several studies in the Mediterranean and European Atlantic archipelagos analysed relationships between both settlers and recruits and their habitat (e.g. Biagi et al., 1998; Bodilis et al., 2003; Dulčić et al., 1997; Francour \& Le Diréach, 1994; García-Rubies \& Macpherson, 1995; Harmelin-Vivien et al., 1995; La Mesa et al., 2002; Le Diréach \& Francour, 1998; Macpherson, 1998; Macpherson et al., 1997; Morato et al., 2003; Planes et al., 1998; Raventós \& Macpherson, 2005; Vigliola et al., 1998). These studies indicate that coastal fish species require shallow areas $(<5 \mathrm{~m})$ with rocky-boulder zones, sandy beaches, or seagrass meadows to settle and/ or recruit on. Other environmental factors, such as hydrodynamism, lunar cycle, or turbidity conditions appeared to be less important. The availability in MPAs of areas suitable for settlement and recruitment of early juveniles can contribute to preserving a well-structured population. However, a general assessment of the degree to which existing and planned MPAs are preserving these nursery areas is still needed.

\section{Expected ecological effects of MPAs at the community level and on habitats}

\section{Protection of biodiversity}

The role of MPAs to conserve biodiversity has been repeatedly advocated (Beger et al., 2003; Salm et al., 2000), but results to date are still scarce and equivocal (Fraschetti et al., 2005; Hughes et al., 2005; Sala \& Knowlton 2006). By preserving species and habitats simultaneously, MPAs would guarantee the persistence of the fundamental processes that sustain biological diversity through supporting the resilience of marine communities in the face of human over-exploitation and climate warming (Graham et al., 2008; Hughes et al., 2003, 2005, 2007; Knowlton, 2004; Mumby et al., 2006, 2007; but see Ledlie et al., 2007).

A few studies have approached the problem of maximising representativeness of a given MPA network to gather the existing biodiversity (e.g. Airamé et al., 2003; Leslie et al., 2003; Sala et al., 2002 ) along with the ability of habitats to protect a self-sustaining assemblage of exploited species (e.g. Parnell et al., 2006), but this issue has seldom been studied in the Mediterranean or Macaronesia. As a unique example, Maiorano et al. (in press) suggest a logical framework to be used for the identification of areas to be targeted for multispecies, spatially explicit conservation actions, and they apply it to a case study along the Ligurian and Tyrrhenian coasts (west-central Italy).

The detrimental effects of over-exploitation/ destruction of marine engineer species, which 


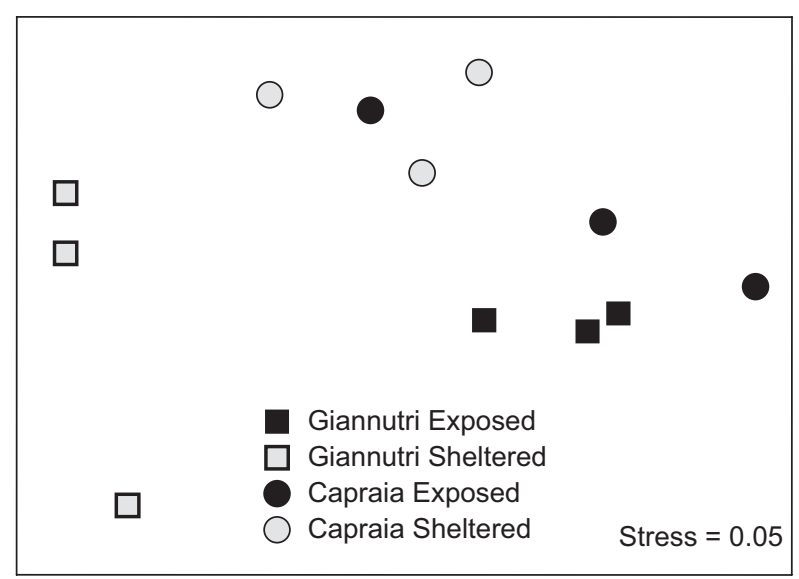

Figure 7. MDS plot showing differences in community structure between exposed and sheltered shores on two islands of the Tuscany Archipelago (Giannutri and Capraia), illustrating the influence of factors other than protection in structuring benthic assemblages (from Benedetti-Cecchi et al., unpublished EMPAFISH data).

include algae, seagrasses, sponges, molluscs, cnidarians and bryozoans (Coleman \& Williams, 2002) make MPAs likely to boost marine biodiversity through enhancing direct and indirect effects of these habitat 'formers' on ecosystems (GarcíaCharton et al., 2000). In addition, there is evidence of faster recovery from disturbance of benthic assemblages within MPAs than assemblages at unprotected locations (Bevilacqua et al., 2006).

The effects of protection measures on benthic assemblages, however, are subject to confusion with other factors, because in addition to indirect trophic effects there is a wide array of environmental and anthropogenic factors influencing distribution, community structure and diversity at multiple spatial and temporal scales (BenedettiCecchi, 2001; Benedetti-Cecchi et al., 2003; Vaselli et al., 2008). As a further example, differences in benthic community structure between exposed and protected conditions are highlighted by data collected during the EMPAFISH project within MPAs in the Tuscany Archipelago (Figure 7).

Comparisons of fish species diversity between MPAs and neighbouring unprotected sites have rendered positive, negative or neutral results (Claudet et al., 2006a, 2008; García-Charton et al., 2004; Halpern, 2003). On the other hand, and because harvesting is likely to produce loss of genetic diversity from exploited populations (Allendorf et al., 2008), MPAs can increase such genetic variation. Again this subject has been seldom approached within the geographical scope of the present review. As an example, although Lenfant (2003) failed to find genetic differences between populations of Diplodus sargus inside and outside the Cerbère-Banyuls marine reserve, PérezRuzafa et al. (2006) showed significant differences in allelic richness for the same species at a broader spatial scale, so that the three MPAs included in this study together provided $97.3 \%$ of the total number of alleles found in all the western Mediterranean populations studied. In addition, the populations sampled in islands tended to have lower allelic richness, lower mean observed heterozygosity and higher heterozygote deficit, than coastal zones (Pérez-Ruzafa et al., 2006). Therefore, this study suggests that fish sanctuaries act as reservoirs for rare alleles, thus precluding their extinction; nevertheless, more insight is needed on this crucial aspect.

\section{Restoration of/changes in assemblage structure}

Marine reserves are expected to induce shifts in fish assemblage structure, derived mainly from the fact that some particular species (in general, large, long-lived predators) are highly vulnerable to fishing, and thus are likely to benefit most from protection measures (Bohnsack, 1996; Plan Development Team, 1990; Roberts \& Polunin, 1993). In the Mediterranean, serranids, sciaenids, sparids, and the larger labrids appear to have benefited most from protection (e.g. Bell, 1983; BayleSempere \& Ramos-Esplá, 1993; Claudet et al., 2006a; Francour, 1994; García-Charton et al., 2004; García-Charton \& Planes, 2002; Garcia-Rubies \& Zabala, 1990; Guidetti, 2006a, 2006b; Guidetti et al., 2005, 2008; Harmelin et al., 1995; Harmelin \& Marinopolous, 1993; Harmelin-Vivien et al., 2008; La Mesa \& Vacchi, 1999; Macpherson et al., 2000, 2002; Micheli et al., 2004; Reñones et al., 2001). As a further example of this, García-Charton et al. (2007) have measured a 3 -fold linear increase in abundance of piscivore fish species within Cabo de Palos - Islas Hormigas marine reserve after 12 years of protection, as compared to an unprotected locality (Figure 2). Ultimately, top predators would become dominant in restored sites, similar to what is observed in the "pristine", undisturbed sites (Jackson et al., 2001; Jackson \& Sala, 2001; Sandin et al., 2008; Stevenson et al., 2007), to which conditions of protected marine sites would attain in the long-term (McClanahan et al., 2007; Russ et al., 2005).

These changes in the species composition and relative abundance of fish species are likely to produce shifts in ecological functioning of the protected ecosystems (Micheli \& Halpern, 2005), as indicated by means of trophic models (McClanahan \& Sala, 1997; Sala, 2004). However, functional studies are still scarce in the case of Mediterranean MPAs. As an exception, the consequences for 
food-web structure of protecting marine communities from trawling have been explored in the Gulf of Castellammare trawling ban zone (Sicily, Italy) using stable isotopes of carbon and nitrogen (Badalamenti et al., 2002, 2008). The observed eight-fold increase in fish biomass (Pipitone et al., 2000) has not been accompanied by substantial size-related trophodynamic shifts in any of the three species of fish studied (anglerfish Lophius budegassa, Mediterranean hake Merluccius merluccius and red mullet Mullus barbatus). Furthermore, the exclusion of trawling had limited effect on fish trophic level at size and no systematic effect on the sources of production supporting any of these three species at the sizes sampled, thus discounting a large bottom-up influence on fish trophodynamics (Badalamenti et al., 2008). Very recently, Mouillot et al. (2008) proposed a new index (called "conservation of biological originality", or CBO index) that can be used to test whether protected areas may protect preferentially the most original species and whether restorative management promotes the re-establishment of the most functionally unique species with particular habitat requirements. Its application in the Bonifacio Strait Natural Reserve (Corsica, France) showed that functional originality was significantly protected $i$ $\mathrm{n}$ the fish assemblage, so that species with the most original functional trait combinations became more abundant after the establishment of protection measures.

As for populations, the effect of MPAs on fish assemblages can be modified (or even obscured) by the interferential effect of variations in habitat structure. Moreover, if we take into account that in general Mediterranean MPAs are established in complex rocky habitats, important target species that associate more with habitats that include a higher proportion of Posidonia oceanica stands and/or sand patches (e.g. small serranids, sea breams, mullids, etc.) (García-Charton \& PérezRuzafa, 2001) can be little affected by protection (García-Charton et al., 2004) when the habitats included are not suitable for them. Environmental differences among protected sites may be larger than protection effects, and habitat heterogeneity within sites can thus lead to patterns of fish abundance independent of protection effects (Figure 8).

\section{Indirect effects on algae and invertebrates}

Empirical and theoretical studies suggest that changes in the abundance of predatory fish can cause ecosystem-wide effects such as trophic cascades (Pinnegar et al., 2000). The cascading effect from predatory fish to sea urchins and

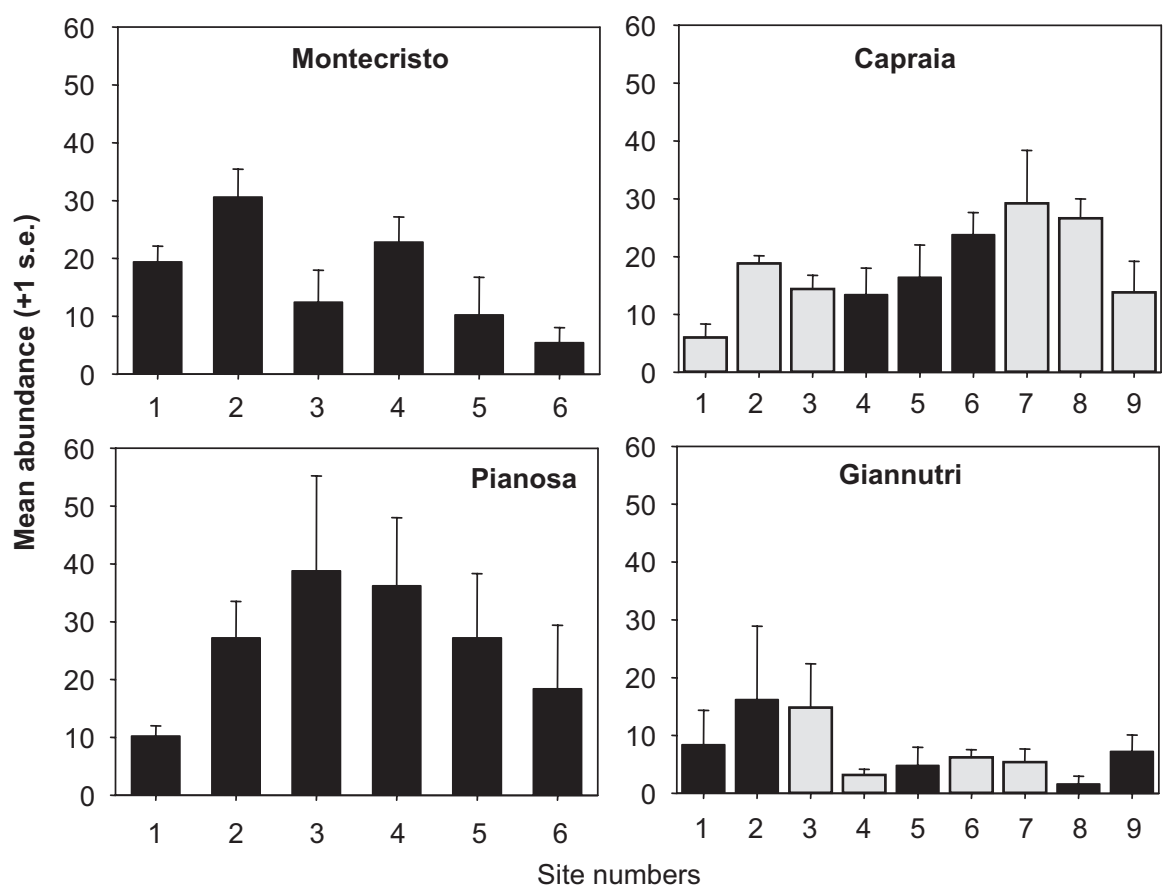

Figure 8. Mean fish abundance (no. indiv. $50 \mathrm{~m}^{-2}$ ) ( \pm standard error of the mean, s.e.) in several randomly located sites within two fully (Montecristo and Pianosa) and two partially (Capraia and Giannutri) protected islands of the Tuscany Archipelago. The partially protected islands alternate fully protected areas (black bars) to open access areas (grey bars). Pianosa is a fully protected Island and it has the largest density of fish, on average. However, patterns of abundance are clearly different among sites $(P<0.008)$ (from Benedetti-Cecchi et al., unpublished EMPAFISH data). 
macroalgae (Guidetti, 2006a; Hereu, 2006; Sala, Boudouresque, \& Harmelin-Vivien, 1998) could lead to the dominance of erect algae whenever predators are abundant within MPAs, thus counteracting the formation of coralline barren areas dominated by sea urchins. Coralline barrens, occurring along the Mediterranean coast when sea urchin (Paracentrotus lividus) densities exceed a threshold of 7-9 urchins per $\mathrm{m}^{2}$ (Hereu, 2004; Verlaque, 1987), can be exceptionally extended in some places - e.g. Ustica island (Cianciolo et al., 2005; Palmeri, 2004); eastern Adriatic coast (Guidetti \& Dulčić, 2007; F. Badalamenti \& J.A. García-Charton, pers. observ.). It has been hypothesised that this ecological shift will occur only once the density of fish predators of sea urchins reaches a threshold of about 15 adult sea breams per $100 \mathrm{~m}^{2}$ (Guidetti \& Sala, 2007). Analogously, the density of the sea urchin Diadema aff. antillarum in the Canarian archipelago varies spatio-temporally, and can reach more than 12 individuals $\mathrm{m}^{-2}$ (Hernández et al., 2008; Tuya et al., 2006), causing large extensions of barren ground, likely related to a generalised decrease in predation pressure due to fishing (Clemente, 2007; Hernández et al., 2005, $2007,2008)$. Nevertheless, predation is often not of sufficient magnitude to substantially alter dense sea urchin populations and cause community-level effects, and other factors, such as predator diversity, refuge availability, recruitment variability, destructive harvesting practices, diseases, and physical conditions can modify the interactions between predatory fish, sea urchins and algae, enabling the persistence of a mosaic of stands of erect algae interspersed with areas dominated by encrusting species (Bruno \& O'Connor, 2005; Clemente et al., 2007; Guidetti, 2007; Guidetti et al., 2003; Hereu et al., 2004, 2005; Hernández et al., 2008; Micheli et al., 2005; Sala, 2004; Sala et al., 1998; Tomás et al., 2004). In any case, restoration of these rocky reefs may be accelerated by intervening and reducing sea urchin populations, as recommended by McClanahan et al. (1996) for Kenyan coral reefs.

\section{Increasing ecosystem stability and resilience}

Increased biodiversity within MPAs is likely to increase community and ecosystem stability (Allison et al., 2003; Benedetti-Cecchi, 2006; McCann, 2000), and thus reduce the variability of ecological responses to disturbance (Fraterrigo \& Rusak, 2008; Pauly et al., 2002) and increase community resilience (Hughes et al., 2005). This could be the phenomenon underlying the hypothesised minimisation of the temporal variations in the abundance of protected populations over the course of an annual cycle (the so-called "buffer effect") (Francour, 1994). Nevertheless, other factors besides the number of species are likely to be responsible for community resistance and resilience induced by the establishment of protection measures, such as the role and identity, spatial distribution, and evenness of the species structuring the community (Bulleri \& Benedetti-Cecchi, 2006).

\section{Detrimental effects due to non-exploitative uses}

Inside MPAs, human activities are being changed in two ways; man as a top predator is generally absent (i.e. removed or limited extractive uses), but in exchange is often present in great numbers as a visitor. MPAs provide goods and services (i.e., attractive underwater flora and fauna, reef structures and seascapes) that contribute to creating heavy tourist loads within them (Badalamenti et al., 2000; Davis \& Tisdell, 1995; Dearden et al., 2006). Physical injury to, or the removal of, a certain species or set of organisms due to visitor trampling on the shore and adjacent shallow water, and scuba-diving or boat anchoring in the sub-littoral, may affect not only an individual population but also, through direct and indirect effects, the whole structure of a community and even the features of the seascape (Francour et al., 2001; Milazzo et al., 2002a).

Scuba-diving is now one of the major forms of commercial use of MPAs around the world (Davis \& Tisdell, 1995). The impact of this recreational activity has been approached mostly by comparing the rate of damage of some fragile species particularly to the presence of divers in frequented versus non- (or less-) frequented sites and/or by direct observations of scuba-divers' behaviour (Barker and Roberts 2004). Sala et al., (1996) used the bryozoan Pentapora fascialis to estimate the likely repercussions of diving onto the coralligenous community in the Medes Islands marine reserve, and observed that this species was 9-10-fold less dense and significantly smaller in size in diverfrequented compared to unfrequented sites. For their part, Garrabou et al. (1998) further studied the same species in the same location, taking advantage of the re-opening of a diving spot in a previously protected site to test experimentally the effect of the presence of divers; they observed that diving drastically reduced the density (by $\sim 50 \%$ in one year, and by $92 \%$ after three years) and height of colonies. High levels of recreational activity did not affect the degree of injury to colonies of the cnidarian Paramuricea clavata in the same marine reserve, although colony death by detachment was the main source of mortality in the MPA, so that 
diving activity was estimated to increase the natural mortality rate of the species by a factor of three (Coma et al., 2004). Direct observations at Ustica on the interactions between divers, substratum and marine organisms in eight common sub-tidal habitats revealed that scuba-diving causes a variety of disturbances to the marine biota (Milazzo et al., unpublished data). A similar study by Herrero et al. (unpublished data) in the Cabo de Palos - Islas Hormigas marine reserve showed that the number and intensity of interactions was significantly reduced by applying simple management measures, such as diver briefings just before diving, and always having a guide to lead the diving groups. Also, Herrero et al. (unpublished data) observed that spatio-temporal variability of algal cover was high and therefore masked any effect of damage due to diving erosion, and that none of the invertebrate taxa included in the analyses showed differences in their density or cover that could be clearly attributed to the activity of recreational divers. Instead, the white sea-fan Eunicella singularis showed significantly higher proportion of colonies fallen as a consequence of divers' passing, and a higher degree of necrosis in the dived sites compared to the no-use area. In addition, experimental simulations of diving impact showed that successive passes by a diver caused the detachment of a quantifiable amount of algae, and detached fragments of the fragile invertebrate species Clavelina dellavallei and Myriapora truncata, causing a significant change in their respective cover or density (Figure 9). In general, while disturbance by recreational divers may be relatively minor on an individual basis, such disturbance becomes ecologically important to the structure of benthic assemblages when many divers are concentrated in a small area. In this case, restricting the number of divers particularly within marine caves - is necessary.

Boat anchoring also has negative impacts in MPAs. A negative effect of anchors on Posidonia oceanica meadows was evidenced in Port-Cros national park by García-Charton et al. (1993), corroborating the results of seminal studies by Robert (1983) and Porcher (1984). In the Ustica Island MPA, anchoring simulation experiments revealed that the damage on Posidonia oceanica was dependent on the type of anchor used, and weighing was critical during the anchoring process (Milazzo et al., 2004a). Further experimental simulations to investigate the response of $P$. oceanica to different intensities of damage at different levels of substratum compactness revealed that disturbance was higher where the substratum was highly penetrable (Ceccherelli

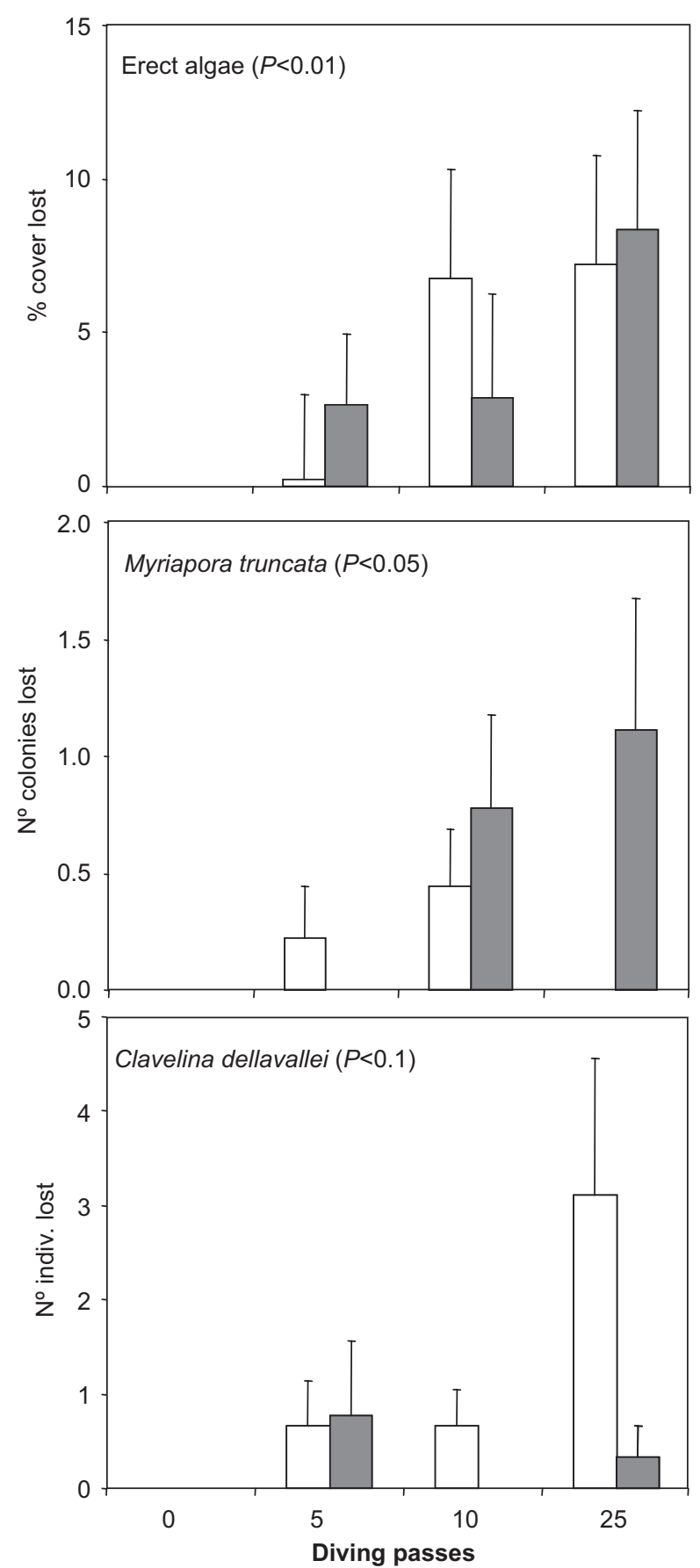

Figure 9. Mean losses in density ( \pm standard error of the mean) of fleshy erect algae, Myriapora truncata and Clavellina dellavallei in $1-\mathrm{m}^{2}$ quadrats with experimentally increasing diving intensity in flat (white) and inclined (grey) bottoms in the Cabo de Palos - Islas Hormigas marine reserve (from Herrero et al., unpublished data). $P$-values of factor Diving intensity in analysis of variance are indicated (factor Slope and its interaction with Diving intensity are not significant in all cases).

et al., 2007). Conversely, the number of leaves per shoot by the end of the study was similar among all treatment combinations, suggesting that this 
was the only phenological feature that showed full recovery.

Trampling by visitors - even at low intensities may be non-sustainable for shallow-water algal assemblages (Milazzo et al., 2002b). The removal of macroalgal fronds caused short-term changes in the associated assemblages and after trampling disturbance ceased, macroalgal recovery was very rapid (less than six months) (Milazzo et al., 2004b). At Ustica, the intervals between two tourist seasons should guarantee a complete recovery of the system, and no particular management solution other than monitoring - needs to be adopted.

Fish-feeding influenced the coastal fish assemblages and caused significant changes in the local distribution (Milazzo et al., 2005) and behaviour (Milazzo et al., 2006) of several species. The nonnatural aggregations of fishes around snorkellers, which result from fish-feeding, also have negative effects on local prey populations (Milazzo et al., 2006). Effective management should seek to limit such activity to specified areas so that human impacts are not felt throughout an entire MPA. The assessment of a snorkelling trail in the CerbèreBanyuls MPA revealed no evidence for negative effects of snorkellers, either on fish assemblages or on algae (Claudet J., Lenfant P. \& Schrimm M., unpublished data).

There is evidence that in Mediterranean MPAs, 'marine-based' tourism and human recreational activities are increasing, however research and monitoring on their effects on the ecosystem functioning are still scarce; this highlights a strong need for substantial research efforts. From a management perspective, areas impacted by tourism are no longer natural, and while activities like those investigated provide good public relations and public education opportunities, they do not necessarily fulfil conservation goals, and they devalue the usefulness of an MPA for research and for other objectives. Non-regulatory approaches, banning or limitation of human presence are the most common management solutions to be adopted on a case-by-case basis.

\section{Part B - Ecological effects of Atlanto- Mediterranean MPAs: a meta-analytical approach}

The effectiveness of MPAs regarding fisheries and ecosystem restoration goals has been widely studied (see the present review), but very few attempts have been made to generalise the ecological effects of MPAs (but see Claudet et al.,
2008; Côté et al., 2001; Guidetti \& Sala, 2007; Halpern, 2003; Micheli et al., 2004; Ojeda-Martínez et al., 2007). The effects of MPAs vary both in direction and magnitude (Claudet et al., 2008; Halpern \& Warner, 2003). Characteristics of MPAs (e.g., age, location, zonation scheme, enforcement, regulation, size, distance from other protected
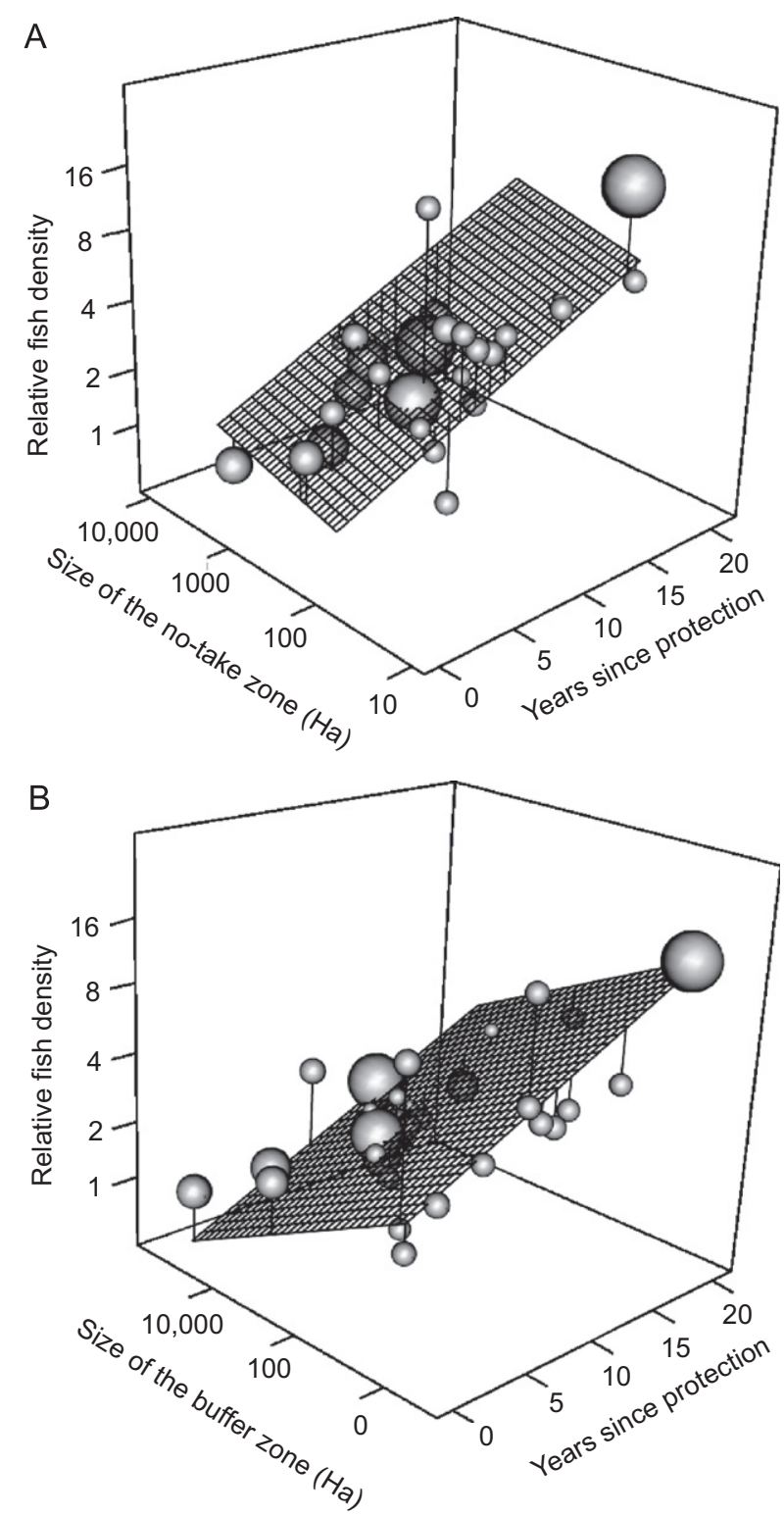

Figure 10. Effects of Mediterranean and Macaronesian marine reserves on commercial fish densities as a function of years since protection and $(A)$ the size of the no-take zone and $(B)$ the size of the buffer zone, as inferred by meta-analysis on data issued from EMPAFISH case studies. Planes give the fitted effect. The size of the points is proportional to the weight of each study. Stems indicate the distance between the calculated weighted effect size and the fitted effect (from Claudet et al., 2008). 
areas, protected habitats) have often been invoked as potential sources of heterogeneity in the responses of marine assemblages to protection (Côté et al., 2001; Guidetti et al., 2008; Guidetti \& Sala, 2007; Halpern, 2003; Halpern \& Warner, 2003; Micheli et al., 2004).

A recent meta-analysis (Claudet et al., 2008) has shed light on the processes underlying such patterns of heterogeneity by examining the response of fish species to protection in the EMPAFISH set of MPAs. There was an overall positive effect of MPAs on the density of commercially exploited fish. Mean densities were 2.5 times larger inside the notake zones (i.e. marine reserves) compared to the adjacent fished areas. This effect was, however, heterogeneous, suggesting that the effects of protection on commercially exploited fishes varied among MPAs. Part of the observed heterogeneity was attributable to time since protection and to the antagonistic effects of the size of the no-take and buffer zones (Claudet et al., 2008) (Figure 10). The older European marine reserves are more effective than newly established reserves in increasing catchable sizes of populations of target fish species and in conserving fish species richness (Claudet et al., 2008). A strong cumulative effect of time since enforcement of protection can be expected for marine reserves, suggesting that the evaluation of their efficacy for re-stocking exploited populations or preserving biodiversity should be framed in a temporal context. The response of commercial species to protection is also reserve size dependent. The reserve sizedependency of the response to protection has strong implications for the spatial management of coastal areas since marine reserves are used for spatial zoning (Claudet et al., 2006a). Increasing the size of the no-take zone resulted in increased density of harvested fishes within the reserve compared to outside (Claudet et al., 2008). In contrast, increasing the size of the buffer zone reduced the effectiveness of the reserve (Claudet et al., 2008). However, our limited understanding of the underlying mechanisms cautions against blind acceptance of this conclusion and further research is needed towards understanding the distribution of fishing effort in the buffer zones and adjacent areas. Moreover, buffer zones are multiple use areas, and the choice of size is a complex problem involving ecology as well as economics and politics. In the case in which the establishment of a buffer zone is required for coastal management purposes, our results suggest that increasing the size of the no-take zone could be a solution mitigating the potentially negative effects of this buffer zone.
Life history and biological/ecological characteristics of fish species may also affect their differential response to protection, and therefore contribute to explaining differences in effectiveness among marine reserves. Another meta-analysis on the same EMPAFISH database (Claudet et al. unpublished work) showed that densities of target fishes were larger in protected than unprotected areas for large-bodied species and, contrary to previous theoretical findings, also for mobile species, even with large home range sizes or yearly displacements. Time of protection strongly affected large species. Even if a positive response to protection was found for non-territorial species with medium to high home ranges and yearly displacements whatever the size of the reserve, the size of the no-take zone had strong effects on these species. The probability that such species benefit from protection increased in large marine reserves that encompass a larger proportion of their displacement range. Increased sizes of buffer zones have negative effects on species with the highest level of displacement. Non-commercial species, whether exploited or not, rarely showed a direct response to protection, either because fishing activities were not detrimental or when the latter is not true, because other indirect effects are reversing the beneficial effects of protection. Implications for management of this second possibility are strong since the prevalent ecosystem approach to marine conservation and fisheries management implies that MPAs should ensure protection to a wide range of species with different life history, biological traits and ecological strategies.

\section{Summary, recommendations and perspectives}

\section{Do the Mediterranean and Macaronesian MPAs accomplish their expected ecological effects?}

From the above review, a considerable amount of empirical evidence emerges to illustrate the ecological effects of MPAs in the Mediterranean and Macaronesia. Hence, we can assert that establishing an MPA in this geographical context is very likely to reverse the population and ecosystem impacts of fisheries on coastal areas (e.g. Goñi, 1998; Kaiser et al., 2006; Lewison et al., 2004; Myers \& Worm, 2003; Tudela, 2000) by: (i) increasing the abundance and/or biomass of target species (fish, decapods, other invertebrates) within MPAs 
compared to unprotected sites; (ii) allowing the recovery of a more "natural" population structure of these commercially harvested populations, by increasing the proportion of larger/older individuals; (iii) enhancing the fecundity of these populations; (iv) enhancing local fishery yields through biomass exportation to surrounding nonprotected areas; and, ( $v$ ) inducing shifts in fish assemblage structure, chiefly by increasing the dominance of large predator species. However, this increased health of the ecosystem becomes in turn an attractor for tourism and diving; if the subsequent over-frequentation is not controlled, damage can occur and some of the MPA effects reversed.

Other expected effects are more subject to uncertainty, or, at best, would need more research, such as: (vi) causing certain density-dependent changes in the life history traits of target species; (vii) protecting the recruitment of commercially important species; (viii) protecting marine biodiversity (including genetic diversity); (ix) causing ecosystem-wide effects such as trophic cascades, and conceivably counteracting detrimental catastrophic shifts in coastal ecosystems; and, (x) increasing community and ecosystem stability, consequently promoting resilience and faster recovery from disturbance.

From the meta-analytical approach performed to ascertain the global effects of Mediterranean and Macaronesian MPAs included as EMPAFISH case studies (Claudet et al., 2008; Claudet unpublished work), further lessons can be extracted. Firstly, the meta-analysis confirmed the wide occurrence of positive responses to protection by fish species targeted by fishing. Moreover, this response is higher in the case of large-bodied species and, unexpectedly, occurs also for very mobile species. On the contrary, species with no commercial value rarely responded to protection measures. Also, it is increasingly clear that the effects of MPAs, although detectable after a few (2-3) years, build up over time so that these effects become more evident the longer the MPA remains functional; their actual importance and magnitude are therefore to be perceived only after several decades. In addition, the size of the no-use zone (i.e. part of the MPA where all human activities, including fishing, are banned) appears to exert a significant influence on the magnitude of the "reserve effect" on fish abundance and biomass; more controversially, increasing the size of the buffer area (i.e. part of the MPA where some uses - e.g. fishing, diving, or swimming are allowed) seems to reduce the effectiveness of the MPA. The latter statement, however, needs further corroboration.

\section{Recommendations for MPA management}

From the above considerations, it can be concluded, as it has been done by other authors in other geographical contexts (Roberts et al., 2001; Rodrigues et al., 2004; Schrope, 2001), that in the Mediterranean and in Macaronesia, MPAs represent an efficient way to conserve marine fishing resources, as well as to protect ecosystems from human nuisances. On the other hand, even in the case of fishing effort being efficiently managed, MPAs have additional properties (such as buffering against wide fluctuations of stock size, or being robust policy measures in the face of assessment uncertainty) that make them desirable as fisheries management tools. In addition, the spatial and permanent character of MPAs often makes them easier to implement than other fisheries management tools.

Ecological goals and objectives of MPAs should be laid out clearly before the MPA is created, or even designed, as they are the basis for the design; for instance, to increase the abundance and/or biomass within MPAs or to protect the recruitment of commercially important species probably require different MPA designs. Goals and objectives should also be defined such that attainment of those objectives can be assessed. Undefined or broadly vague objectives should be avoided as MPA effectiveness cannot then be monitored and evaluated (Claudet \& Pelletier, 2004). Nevertheless, we caution that a degree of uncertainty remains on the effects of MPAs, and also that some expected benefits still need to be supported by empirical evidence; thus, the benefits the MPA are going to supply should not be exaggerated, unless additional scientific information is provided (see below). In addition, it should be clearly stated that goals and objectives are attained in the long-term, because, although many benefits will become apparent soon after protection, full ecosystem recovery will require decades to tens of decades to occur. Among MPA goals, MPA research and monitoring is to be considered as an explicit objective of MPA creation, since MPAs constitute true natural experiments of species, communities and ecosystem recoveries from decades or centuries of fisheries exploitation, and are practically the only places left where this knowledge can be obtained.

Site selection criteria to establish new MPAs should be based on sound scientific information. To ensure that MPA objectives can be achieved, it is crucial that the criteria used to designate MPA areas include concerns of environmental quality, importance of the site for reproduction of overexploited or protected species, and presence of 
high biodiversity. Particularly good candidate sites are also those that match these criteria, but are embedded in an otherwise poor environment. The connectivity of marine populations should also ensure the recovery of biodiversity under these circumstances.

The process of designing and zoning an MPA, which should be intimately linked to the stated objectives, has usually involved little scientific justification in the past throughout the region (Badalamenti et al., 2000; Francour et al., 2001; Fraschetti et al., 2002). However, identifying meaningful ecological variables represents an important tool for decision making. In particular, in addition to considerations of reproductive output, dispersal, mobility, connectivity and size of the organisms to be protected, value should also be ascribed to spatial heterogeneity of habitats, as additional driving information for the zoning and implementation of MPAs. MPAs should ideally include as many habitat types as possible, because critical information is often lacking on species life cycles and habitat preferences throughout the life span of these species. From our results, we conclude that large MPAs are preferred to smallto-medium-sized ones; in addition, sizes of each zone within the MPA should be scaled to maximise the size of the no-take area relative to buffer zones. Present models (e.g. Pérez-Ruzafa et al., 2008 - this volume) suggest that an upper limit seems to exist, further from which the ideal is to build a network of several MPAs.

The planning of management measures for MPAs should comprise the development of specific protocols and metrics to monitor and assess enforcement levels within MPAs (see Guidetti et al., 2008). Specifically, tourism activities (especially diving) should be oriented towards a sustainable use of the protected area; in particular, quotas should be established and adequately enforced in order to keep human frequentation below the carrying capacity of the MPA. As an important (and often neglected) issue, planning activities should include the provision of time and resources to conduct rigorous baseline 'before', in addition to 'after' studies, with a view to monitoring studies to be conducted in MPAs (see below).

The monitoring of MPAs constitutes a key element in their long-term success. This monitoring should be comprehensive and holistic, integrating concerns related to biological and ecological variables with socio-economic and governability ones (Pomeroy et al., 2005). This means that monitoring should ideally begin before the design and implementation process, and have continuity in order to show the long-term evolution of key variables during the time span of the protected area. Experimental designs for ascertaining the effects of MPA should include the monitoring of a number of areas in protected and non-protected zones, including therefore spatial and temporal replication (Edgar et al., 2004; Fraschetti et al., 2002; García-Charton \& Pérez-Ruzafa, 1999; GarcíaCharton et al., 2000; Guidetti, 2002). Monitoring actions should be undertaken on a periodic basis, and always under the direct advice of competent scientific personnel, as our experience highlights the need for more coordinated and continuous monitoring activities, including the currently lacking assessment of achievement of conservation goals.

\section{Recommendations for MPA research}

In order to better understand the way MPAs work, and to build a set of criteria to design adequate MPA networks, we need more studies to fulfil the following MPA research gaps (see also Sale et al., 2005):

- Effects of MPAs on fish density and biomass at regional scales, comparing the spatial patterns in fish abundance and biomass from unprotected sites in geographical areas with MPAs and similar, unprotected sites, in geographical areas far from MPAs, taking advantage of existing and (above all) future MPAs as true ecological experiments at broad geographical scales.

- Importance of density-dependent shifts in life history traits within MPAs (individual and population growth, reproductive potential, feeding behaviour and diet, natural mortality, etc.), and capability of these changes to reverse evolutionary shifts due to the selective mortality of commercially exploited fish species induced by fishing.

- Biological and ecological mechanisms ultimately responsible for the "spill-over effect" (i.e. net emigration of adult and juvenile fishes), through tagging and acoustic tracking studies.

- Study of habitat selection in fish and the spatial distribution and continuity of habitats inside and outside MPAs (using GIS), in order to assess ability of protected habitats to support a selfsustaining assemblage of exploited species, as well as to allow fish movements to occur.

- Connectivity of marine populations subject to protection, by tagging studies (using external, chemical or genetic tags), coupled with studies aimed at ascertaining the larval dispersal of key species, and hydrodynamic studies to establish 
the patterns of oceanographic currents at multiple spatial and temporal scales.

- Capacity of (and the characteristics required by) MPAs to protect colonisation, settlement and recruitment of marine populations of important species.

- Ability of existing and/or planned MPA networks to maximise the representativeness of marine biodiversity (including genetic, habitat - seascape, species and functional diversity), by developing the adequate methodological improvements.

- Degree to which MPA-driven changes in structural properties of marine communities, such as the number, identity, and relative abundance of individual species and species groups, are able to cause shifts in the ecological functioning of the ecosystem.

- Generality, extent and ecological mechanisms of trophic cascades within MPAs (e.g. predatory fish-sea urchins-macroalgae), and their ability to counteract undesirable ecosystem-wide effects of fishing (e.g. expansion of urchin barren grounds).

- Role of MPAs in promoting resilience and faster recovery of marine ecosystems from humandriven disturbances (including climate change).

- Effectiveness and feasibility of possible restoration actions within MPAs (e.g. manual reduction of sea urchin numbers) to be taken in order to accelerate the reversal of the detrimental effects of over-fishing.

\section{Concluding remarks}

Bearing these research gaps in mind, priority operational objectives should be established for future EU research strategy relevant to this topic (García-Charton et al., 2008). However, due to the urgency of adopting management measures in the face of the rapid biodiversity loss, the situation requires managers to plan more in the long-term and more with a precautionary perspective, and scientists to think more in the short-term - such as giving answers to managers without being absolutely sure of their conclusions (thus presenting associated levels of uncertainty), until these research gaps are adequately fulfilled.

\section{Acknowledgements}

This work has been carried out with financial support from the Commission of the European
Community, specific RTD programme "Specific Support to Policies", SSP-2003-006539 “European Marine Protected Areas as Tools for Fisheries Management and Conservation (EMPAFISH)". This work does not necessarily reflect the Commission's views and in no way anticipates the Commission's future policy in this area.

\section{References}

Abdulla, A., Gomei, M., Maison, E., \& Piante, C. (in press). Status of marine protected areas in the Mediterranean Sea. Málaga: IUCN \& France: WWF.

Abesamis, R. A., Russ, G. R., \& Alcala, A. C. (2006). Gradients of abundance of fish across no-take marine reserve boundaries: Evidence from Philippine coral reefs. Aquatic Conservation: Marine and Freshwater Ecosystems, 16, 349-371.

Afonso, P., Fontes, J., Holland, K. N., \& Santos, R. S. (2008). Social status determines behaviour and habitat usage in a temperate parrotfish: Implications for marine reserve design. Marine Ecology Progress Series, 359, 217-227.

Agardi, T. (2005). Global marine conservation policy versus site-level implementation: The mismatch of scale and its implications. Marine Ecology Progress Series, 300, 242-248.

Airamé, S., Dugan, J. E., Lafferty, K. D., Leslie, H., McArdle, D. A., \& Warner, R. R. (2003). Applying ecological criteria to marine reserve design: A case study from the California Channel Islands. Ecological Applications, 13, 170-184.

Alcala, A. C., Russ, G. R., Maypa, A. P., \& Calumpong, H. P. (2005). A long-term, spatially replicated experimental test of the effect of marine reserves on local fish yields. Canadian Journal of Fisheries and Aquatic Sciences, 62, 98-108.

Allendorf, F. W., England, P. R., Luikart, G., Ritchie, P. A., \& Ryman, N. (2008). Genetic effects of harvest on wild animal populations. Trends in Ecology and Evolution, 23, 327-337.

Allison, G. W., Gaines, S. D., Lubchenco, J., \& Possinghan, H. P. (2003). Ensuring persistence of marine reserves: Catastrophes require adopting an insurance factor. Ecological Applications, 13, S8-S24.

Allison, G. W., Lubchenco, J., \& Carr, M. H. (1998). Marine reserves are necessary but not sufficient for marine conservation. Ecological Applications, 8, S79-S92.

Astruch, P., Lenfant, P., Binche, J.-L., Pastor, J., \& Dalias, N. (2007). Survey of dusky grouper (Epinephelus marginatus, Lowe 1834) by telemetry inside the marine reserve of Cerbère-Banyuls (France, North Western Mediterranean). In A. Pérez-Ruzafa, E. Hoffman, J. Boncoeur, J. A. García-Charton, C. Marcos, F. Salas, T. K. Sorensen, \& O. Vestergaard (Eds.), European symposium on marine protected areas as a tool for fisheries management and ecosystem 
conservation. Emerging science and interdisciplinary approaches. Abstracts Book p. 95. Empafish and protect proyects. Murcia: Editum.

Attwood, C. G., \& Bennett, B. A. (1994). Variation in dispersal of galjoen (Coracinus capensis) (Teleostei: Coracinidae) from a marine reserve. Canadian Journal of Fisheries and Aquatic Sciences, 51, 1247-1257.

Badalamenti, F., D’Anna, G., Pinnegar, J. K., \& Polunin, N. V. C. (2002). Size-related trophodynamic changes in three target fish species recovering from intensive trawling. Marine Biology, 141, 561-570.

Badalamenti, F., Ramos-Esplá, A., Voultsiadou, E., Sanchez-Lisazo, J. L., D’Anna, G., Pipitone, C., et al. (2000). Cultural and socio-economic impacts of Mediterranean marine protected areas. Environmental Conservation, 27, 1-16.

Badalamenti, F., Sweeting, C. J., Polunin, N. V. C., Pinnegar, J., D’Anna, G., \& Pipitone, C. (2008). Limited trophodynamics effects of trawling on three Mediterranean fishes. Marine Biology, 154, 765-773.

Balmford, A., Bennun, L., ten Brink, B., Cooper, D., Côte, I. M., Crane, P., et al. (2005). The Convention on Biological Diversity's 2010 target. Science, 307, 212-213.

Barker, N. H. L., \& Roberts, C. (2004). Scuba diver behaviour and the management of diving impacts on coral reefs. Biological Conservation, 120, 481-489.

Bayle-Sempere, J. T., \& Ramos-Esplá, A. A. (1993). Some population parameters as indicators to assess the "reserve effect" on the fish assemblage. In C. F. Boudouresque, M. Avon, \& C. Pergent-Martini (Eds.), Indicateurs biologiques, \& physico-chimiques (pp. 189-214). France: GIS Posidonie Publ.

Beddington, J. R., Agnew, D. J., \& Clark, C. W. (2007). Current problems in the management of marine fisheries. Science, 316, 1713-1716.

Beger, M., Jones, G. P., \& Munday, P. L. (2003). Conservation of coral reef biodiversity: A comparison of reserve selection procedures for coral and fishes. Biological Conservation, 111, 53-62.

Bell, J. D. (1983). Effects of depth and marine reserve fishing restrictions on the structure of a rocky reef fish assemblage in the northwestern Mediterranean-Sea. Journal of Applied Ecology, 20, 357-369.

Benedetti-Cecchi, L. (2001). Variability in abundance of algae and invertebrates at different spatial scales on rocky sea shores. Marine Ecology Progress Series, 215, 79-92.

Benedetti-Cecchi, L. (2006). Understanding the consequences of changing biodiversity on rocky shores: How much have we learned from past experiments? Journal of Experimental Marine Biology and Ecology, 338, 193-204.

Benedetti-Cecchi, L., Bertocci, I., Micheli, F., Maggi, E., Fosella, T., \& Vaselli, S. (2003). Implications of spatial heterogeneity for management of marine protected areas (MPAs): Examples from assemblages of rocky coasts in the northwest Mediterranean. Marine Environmental Research, 55, 429-458.

Berkeley, S. A., Hixon, M. A., Larson, R. J., \& Love, M. S. (2004). Fisheries sustainability via protection of age structure and spatial distribution of fish populations. Fisheries, 29, 23-32.

Bevilacqua, S., Terlizzi, A., Fraschetti, S., Russo, G. F., \& Boero, F. (2006). Mitigating human disturbance: Can protection influence trajectories of recovery in benthic assemblages? Journal of Animal Ecology, 75, 908-920.

Biagi, F., Gambaccini, S., \& Zazzetta, M. (1998). Settlement and recruitment in fishes: The role of coastal areas. Italian Journal of Zoology, 65, 269-274.

BIOMEX. (2005). BIOMEX (Assessment of biomass export from marine protected areas and its impact on fisheries in the western Mediterranean Sea) Final Report. 5th FP, EC (500pp.).

Birkeland, C., \& Dayton, P. K. (2005). The importance in fishery management of leaving the big ones. Trends in Ecology and Evolution, 20, 366-368.

Blyth-Skyrme, R., Kaiser, M. J., Hiddink, J. G., EdwardsJones, G., \& Hart, P. J. B. (2006). Conservation benefits of temperate marine protected areas: Variation among fish species. Conservation Biology, 20, 811-820.

Bodilis, P., Ganteaume, A., \& Francour, P. (2003). Presence of 1 year-old dusky groupers along the French Mediterranean coast. Journal of Fish Biology, 62, 242-246.

Bohnsack, J. A. (1996). Maintenance and recovery of reef fishery productivity. In N. V. C. Polunin, \& C. M. Roberts (Eds.), Reef fisheries (pp. 283-313). London: Chapman \& Hall.

Brito, A., Barquín, J., Falcón, J. M., González, G., Clemente, S., Hernández, J. C., et al. (2006a). Valoración "in situ" de las poblaciones de especies indicadoras del efecto reserva en la reserva marina de La Graciosa y los islotes del norte de Lanzarote. Viceconsejería de Pesca del Gobierno de Canarias. Universidad de La Laguna (107pp.)

Brito, A., Barquín, J., Falcón, J. M., González, G., Clemente, S., Hernández, J. C., et al. (2006b). Seguimiento de la reserva de El Hierro y estudio de recursos marisqueros. Viceconsejería de Pesca del Gobierno de Canarias. Universidad de La Laguna (75pp.).

Browman, H. I., \& Stergiou, K. I. (2004). Marine protected areas as a central element of ecosystembased management: Defining their location, size and number. Marine Ecology Progress Series, 274, 271-272.

Bruno, J. F., \& O'Connor, M. I. (2005). Cascading effects of predator diversity and omnivory in a marine food web. Ecology Letters, 8, 1048-1056.

Bulleri, F., \& Benedetti-Cecchi, L. (2006). Mechanisms of recovery and resilience of different components of mosaics of habitats on shallow rocky reefs. Oecologia, 149, 482-492.

Camilleri, M. (2003). Background to the establishment of the 25 mile Fisheries Conservation Zone around the Maltese islands. In Proceedings of the APS Seminar on Ecosystem based fisheries management in the Mediterranean (pp. 99-106). Malta: APS Bank Publications. 
Ceccherelli, G., Davide, C., \& Milazzo, M. (2007). Shortterm response of the slow growing seagrass Posidonia oceanica to simulated anchor impact. Marine Environmental Research, 63, 341-349.

Chapman, M. R., \& Kramer, D. L. (1999). Gradients in coral reef fish density and size across the Barbados Marine Reserve boundary: Effects of reserve protection and habitat characteristics. Marine Ecology Progress Series, 181, 81-96.

Cianciolo, C., Milazzo, M., Badalamenti, F., \& Chemello, R. (2005). Effetti indiretti del pascolamento dei ricci sul benthos costiero: Variazioni nella malacofauna. Biologia Marina Mediterranea, 12, 261-264.

Claudet, J., \& Pelletier, D. (2004). Marine protected areas and artificial reefs: A review of the interactions between management and scientific studies. Aquatic Living Resources, 17, 129-138.

Claudet, J., Pelletier, D., Jouvenel, J.-Y., Bachet, F., \& Galzin, R. (2006a). Assessing the effects of marine protected area (MPA) on a reef fish assemblage in a northwestern Mediterranean marine reserve: Identifying community-based indicators. Biological Conservation, 130, 349-369.

Claudet, J., Osenberg, C. W., Benedetti-Cecchi, L., Domenici, P., García-Charton, J. A., Pérez-Ruzafa, A., et al. (2008). Marine reserves: Size and age do matter. Ecology Letters, 11, 481-489.

Claudet, J., Roussel, S., Pelletier, D., \& Rey-Valett, H. (2006b). Spatial management of near shore coastal areas: The use of marine protected areas (MPAs) in a fisheries management context. Vie et Milieu, 56, 301-305.

Clemente, S. (2007). Evolución de las poblaciones del erizo Diadema aff. antillarum en Canarias y valoración de la depredación como factor de control. Ph.D. Thesis, University of La Laguna.

Clemente, S., Hernández, J. C., Toledo, K., \& Brito, A. (2007). Predation upon Diadema aff. antillarum in barren grounds in the Canary Islands. Scientia Marina, 71, 745-754.

Coleman, F. C., \& Williams, S. L. (2002). Overexploiting marine ecosystem engineers: Potential consequences for biodiversity. Trends in Ecology and Evolution, 17, 40-44.

Coma, R., Pola, E., Ribes, M., \& Zabala, M. (2004). Longterm assessment of temperate octocoral mortality patterns, protected vs. unprotected areas. Ecological Applications, 14, 1466-1478.

Côté, I. M., Mosqueira, I., \& Reynolds, J. D. (2001). Effects of marine reserve characteristics on the protection of fish populations: A meta-analysis. Journal of Fish Biology, 59, 178-189.

Cury, P. M. (2004). Tuning the ecoscope for the ecosystem approach to fisheries. Marine Ecology Progress Series, 274, 272-275.

Cury, P. M., Shin, Y.-J., Planque, B., Durant, J. M., Fromentin, J.-M., Kramer-Schadt, S., et al. (2008). Ecosystem oceanography for global change in fisheries. Trends in Ecology and Evolution, 23, 338-346.

Dankel, D. J., Skagen, D. W., \& Ulltang, O. (2008). Fisheries management in practice: Review of 13 commercially important fish stocks. Reviews on Fish Biology and Fisheries, 18, 201-233.

Davis, D., \& Tisdell, C. (1995). Recreational scuba-diving and carrying capacity in marine protected areas. Ocean, and Coastal Management, 26, 19-40.

Daw, T., \& Gray, T. (2005). Fisheries science and sustainability in international policy: A study of failure in the European Union's Common Fisheries Policy. Marine Policy, 29, 189-197.

Dearden, P., Bennett, M., \& Rollins, R. (2006). Implications for coral reef conservation of diver specialization. Environmental Conservation, 33, 353-363.

Dimech, M., Camilleri, M., Hiddink, J. G., Kaiser, M. J., Ragonese, S., \& Schembri, P. J. (in press). Differences in demersal community structure and body-size spectra within and outside the Maltese Fishery Management Zone (FMZ). Scientia Marina.

Dufour, V., Jouvenel, J. Y., \& Galzin, R. (1995). Study of a Mediterranean reef fish assemblage - comparisons of population-distributions between depths in protected and unprotected areas over one decade. Aquatic Living Resources, 8, 17-25.

Dugan, J. E., \& Davis, G. E. (1993). Applications of marine refugia to coastal fisheries management. Canadian Journal of Fishieries and Aquatic Sciencies, 50, 2029-2042.

Dulčić, J., Kraljevic, M., Grbec, B., \& Pallaoro, A. (1997). Composition and temporal fluctuations of inshore juvenile fish populations in the Kornati Archipelago, eastern middle Adriatic. Marine Biology, 129, 267-277.

Dulvy, N. K., Sadovy, Y., \& Reynolds, J. D. (2003). Extinction vulnerability in marine populations. Fish and Fisheries, 4, 25-64.

Dunlop, E. S., Shuter, B. J., \& Dieckmann, U. (2007). Demographic and evolutionary consequences of selective mortality: Predictions from an eco-genetic model for smallmouth bass. Transactions of the American Fisheries Society, 136, 749-765.

Edgar, G. J., Bustamante, R. H., Fariña, J.-M., Calvopiña, M., Martínez, C., \& Toral-Granda, M. V. (2004). Bias in evaluating the effects of marine protected areas: The importance of baseline data for the Galapagos Marine Reserve. Environmental Conservation, 31, 212-218.

European Environment Agency. (2006). Priority issues in the Mediterranean environment. EEA Report No. 4/ 2006.

Falcón, J. M., Brito, A., García-Charton, J. A., Dorta, C., Martín-Sosa, P., Hernández, J. C., et al. (2007a). Evidence of the effects of protection on littoral fish communities in and around La Restinga Marine Reserve (El Hierro, Canary Islands, Central-Eastern Atlantic). In A. Pérez-Ruzafa, E. Hoffman, J. Boncoeur, J. A. García-Charton, C. Marcos, F. Salas, T. K. Sorensen, \& O. Vestergaard (Eds.), European symposium on marine protected areas as a tool for fisheries management and ecosystem conservation. Emerging science and interdisciplinary approaches. Abstracts Book p. 95. Empafish and Protect proyects. Murcia: Editum.

Falcón, J. M., Brito, A., García-Charton, J. A., MartínSosa, P., Dorta, C., Hernández, J. C., et al. (2007b). 
Evaluating the effects of protection on littoral fish communities: La Graciosa Marine Reserve (Canary Islands, Central-Eastern Atlantic) case study. In A. Pérez-Ruzafa, E. Hoffman, J. Boncoeur, J. A. GarcíaCharton, C. Marcos, F. Salas, T. K. Sorensen, \& 0. Vestergaard (Eds.), European symposium on marine protected areas as a tool for fisheries management and ecosystem conservation. Emerging science and interdisciplinary approaches. Abstracts Book p. 96. Empafish and Protect proyects. Murcia: Editum.

Follesa, M. C., Cuccu, D., Cannas, R., Cabiddu, S., Murenu, M., Sabatini, A., et al. (2008). Effects of marine reserve protection on spiny lobster (Palinurus elephas Fabr., 1787) in a central western Mediterranean area. Hydrobiologia, 606, 63-68.

Follesa, M. C., Cuccu, D., Cannas, R., Sabatini, A., \& Cau, A. (2007). Emigration and retention of Palinurus elephas (Fabricius, 1787) in a central western Mediterranean marine protected area. Scientia Marina, 71, 279-285.

Francis, R. C., Hixon, M. A., Clarke, M. E., Murawski, S., \& Ralston, S. (2007). Ten commandments for ecosystem-based fisheries scientists. Fisheries, 32, 217-233.

Francour, P. (1994). Pluriannual analysis of the reserve effect on ichthyofauna in the Scandola natural reserve Corsica, Northwestern Mediterranean. Oceanologica Acta, 17, 309-317.

Francour, P., \& Le Diréach, L. (1994). Recrutement de l'ichtyofaune dans l'herbier superficiel à Posidonia oceanica de la Réserve Naturelle de Scandola (Corse, Méditerranée nord-occidentale): Données préliminaires. Travaux Scientifiques du Parc Naturel Régional de Corse (France), 46, 71-91.

Francour, P., Harmelin, J.-G., Pollard, D., \& Sartoretto, S. (2001). A review of marine protected areas in the northwestern Mediterranean region: Siting, usage, zonation and management. Aquatic Conservation: Marine and Freshwater Ecosystems, 11, 155-188.

Fraschetti, S., Terlizzi, A., Bussotti, S., Guarnieri, G., D'Ambrosio, P., \& Boero, F. (2005). Conservation of Mediterranean seascapes: Analyses of existing protection schemes. Marine Environmental Research, 59, 309-332.

Fraschetti, S., Terlizzi, A., Micheli, F., Benedetti-Cecchi, L., \& Boero, F. (2002). Marine protected areas in the Mediterranean Sea: Objectives, effectiveness and monitoring. P.S.Z.N. I: Marine Ecology, 23, 190-200.

Fraterrigo, J. M., \& Rusak, J. A. (2008). Disturbancedriven changes in the variability of ecological patterns and processes. Ecology Letters, 11, 756-770.

García-Charton, J. A., Bayle-Sempere, J. T., SánchezLizaso, J. L., Chiesa, P., Llauradó, F., Pérez, C., et al. (1993). Respuesta de la pradera de Posidonia oceanica y su ictiofauna asociada al anclaje de embarcaciones en el parque nacional de Port-Cros (Francia). Publicaciones Especiales del Instituto Español de Oceanografía, 11, 423-430.

García-Charton, J. A., Esparza, O., Rodríguez-Hernández, A., Saber, S., Treviño, J., Herrero, A., et al. (2007). Estudios de seguimiento de la Reserva Marina de Cabo de Palos - Islas Hormigas - 2007. Consejería de Agricultura y Agua, Comunidad Autónoma de la Región de Murcia.

García-Charton, J. A., Marcos, C., Salas, F., \& PérezRuzafa, A. (2008). MPAs in Europe: Challenges and opportunities. MPA News, 9, 3.

García-Charton, J. A., \& Pérez-Ruzafa, A. (1999). Ecological heterogeneity and the evaluation of the effects of marine reserves. Fisheries Research, 42, $1-20$.

García-Charton, J. A., \& Pérez-Ruzafa, A. (2001). Spatial pattern and the habitat of a SW Mediterranean reef fish assemblage. Marine Biology, 138, 917-934.

García-Charton, J. A., Pérez-Ruzafa, A., Sánchez-Jerez, P., Bayle-Sempere, J. T., Reñones, O., \& MorenoLampreave, D. (2004). Multi-scale spatial heterogeneity, habitat structure, and the effect of marine reserves on Western Mediterranean rocky reef fish assemblages. Marine Biology, 144, 161-182.

García-Charton, J. A., \& Planes, S. (2002). Etude de l'impact de la réserve Naturelle Marine de Cerbèrel Banyuls comme source d'exportation de poissons littoraux adultes vers les zones avoisinantes. Rapport EPHE. Conseil Général des Pyrénées-Orientales, 43pp.+6 annexes.

García-Charton, J. A., Williams, I. D., Pérez-Ruzafa, A., Milazzo, M., Chemello, R., Marcos, C., et al. (2000). Evaluating the ecological effects of Mediterranean marine protected areas: Habitat, scale and the natural variability of ecosystems. Environmental Conservation, 27, 159-178.

García-Rubies, A., \& Macpherson, E. (1995). Substrate use and temporal pattern of recruitment in juvenile fishes of the Mediterranean littoral. Marine Biology, 124, 35-42.

Garcia-Rubies, A., \& Zabala, M. (1990). Effects of total fishing prohibition on the rocky fish assemblages of Medes Islands marine reserve (NW Mediterranean). Scientia Marina, 54, 317-328.

Gårdmark, A., Jonzén, N., \& Mangel, M. (2005). Densitydependent body growth reduces the potential of marine reserves to enhance yields. Journal of Applied Ecology, 43, 61-69.

Garrabou, J., Sala, E., Arcas, A., \& Zabala, M. (1998). The impact of diving on rocky sublittoral communities: A case study of a bryozoan population. Conservation Biology, 12, 302-312.

Gell, F. R., \& Roberts, C. M. (2003). Benefits beyond boundaries: The fishery effects of marine reserves. Trends in Ecology and Evolution, 18, 448-456.

Gerber, L. R., \& Heppell, S. S. (2004). The use of demographic sensitivity analysis in marine species conservation planning. Biological Conservation, 120, 121-128.

Gianguzza, P., Chiantore, M., Bonaviri, C., CattaneoVietti, R., Vielmini, I., \& Riggio, S. (2006). The effects of recreational Paracentrotus lividus fishing on distribution patterns of sea urchins at Ustica Island MPA (Western Mediterranean, Italy). Fisheries Research, $81,37-44$. 
Gillanders, B. N., Sánchez-Jerez, P., Bayle-Sempere, J. T., \& Ramos-Esplá, A. A. (2001). Trace elements in otholits of the two-banded bream from a coastal region in the south-west Mediterranean: Are there differences among location? Journal of Fish Biology, 59, 350-363.

Gilliland, P. M., \& Laffoley, D. (2008). Key elements and steps in the process of developing ecosystem-based marine spatial planning. Marine Policy, 32, 787-796.

Gollasch, S. (2006). Overview of introduced aquatic species in European navigational and adjacent waters. Helgoland Marine Research, 60, 84-89.

Goñi, R. (1998). Ecosystem effects of marine fisheries: An overview. Ocean, and Coastal Management, 40, 37-64.

Goñi, R., Adlerstein, S., Álvarez-Berastegui, D., Forcada, A., Reñones, O., Criquet, G., et al. (2008). Spillover from six western Mediterranean marine protected areas: Evidence from artisanal fisheries. Marine Ecology Progress Series, 366, 159-174.

Goñi, R., Quetglas, A., \& Reñones, O. (2003). Size at maturity, fecundity and reproductive potential of a protected population of the spiny lobster Palinurus elephas (Fabricius, 1787) from the western Mediterranean. Marine Biology, 143, 583-592.

Goñi, R., Quetglas, A., \& Reñones, O. (2006). Spillover of spiny lobsters Palinurus elephas from a marine reserve to an adjoining fishery. Marine Ecology Progress Series, 308, 207-219.

Goñi, R., Reñones, O., \& Quetglas, A. (2001). Dynamics of a protected Western Mediterranean population of the European spiny lobster Palinurus elephas (Fabricius, 1787) assessed by trap surveys. Marine and Freshwater Research, 52, 1577-1587.

González-Wangüemert, M. (2004). Estructura genética de las poblaciones de Diplodus sargus en el SE peninsular en relación con la protección de áreas marinas. Ph.D. Thesis, University of Murcia, Spain.

González-Wangüemert, M., Pérez-Ruzafa, A., Marcos, C., \& García-Charton, J. A. (2004). Genetic differentiation of Diplogus sargus (Pises: Sparidae) populations in SW Mediterranean. Biological Journal of the Linnean Society, 82, 249-261.

Graham, N. A. J., McClanahan, T. R., MacNeil, M. A., Wilson, S. K., Polunin, N. V. C., \& Jennings, S. (2008). Climate warming, marine, protected areas and the ocean-scale integrity of coral reef ecosystems. PLOS One, 3, 1-9.

Guidetti, P. (2002). The importance of experimental design in detecting the effects of protection measures on fish in Mediterranean MPAs. Aquatic Conservation: Marine and Freshwater Ecosystems, 12, 619-634.

Guidetti, P. (2006a). Marine reserves reestablish lost predatory interactions and cause community changes in rocky reefs. Ecological Applications, 16, 963-976.

Guidetti, P. (2006b). Potential of marine reserves to cause community-wide changes beyond their boundaries. Conservation Biology, 21, 540-545.

Guidetti, P. (2007). Predator diversity and density affect levels of predation upon strongly interactive species in temperate rocky reefs. Oecologia, 154, 513-520.
Guidetti, P., Bussotti, S., \& Boero, F. (2005). Evaluating the effects of protection on fish predators and sea urchins in shallow artificial rocky habitats: A case study in the northern Adriatic Sea. Marine Environmental Research, 59, 333-348.

Guidetti, P., \& Dulčić, J. (2007). Relationships among predatory fish, sea urchins and barrens in Mediterranean rocky reefs across a latitudinal gradient. Marine Environmental Research, 63, 168-184.

Guidetti, P., Fraschetti, S., Terlizzi, A., \& Boero, F. (2003). Distribution patterns of sea urchins and barrens in shallow Mediterranean rocky reefs impacted by the illegal fishery of the rocky-boring mollusc Lithophaga lithophaga. Marine Biology, 143, 1135-1142.

Guidetti, P., Milazzo, M., Bussotti, S., Molinari, A., Murenu, M., Pais, A., et al. (2008). Italian marine reserve effectiveness: Does enforcement matter? Biological Conservation, 141, 699-709.

Guidetti, P., \& Sala, E. (2007). Community-wide effects of marine reserves in the Mediterranean Sea. Marine Ecology Progress Series, 335, 43-56.

Guidetti, P., Terlizzi, A., \& Boero, F. (2004). Effects of the edible sea urchin, Paracentrotus lividus, fishery along the Apulian rocky coasts (SE Italy, Mediterranean Sea). Fisheries Research, 66, 287-297.

Halpern, B. S. (2003). The impact of marine reserves: Do reserves work and does reserve size matter? Ecological Applications, 13, 117-137.

Halpern, B. S., Walbridge, S., Selkoe, K. A., Kappel, C. V., Micheli, F., D’Agrosa, C., et al. (2008). A global map of human impact on marine ecosystems. Science, 319, 948-952.

Halpern, B. S., \& Warner, R. R. (2003). Matching marine reserve design to reserve objectives. Proceedings of the Royal Society, London, B, 270, 1871-1878.

Harley, C. D. G., Hughes, A. R., Hultgren, K. M., Miner, B. G., Sorte, C. J. B., Thornber, C. S., et al. (2006). The impacts of climate change in coastal marine systems. Ecology Letters, 9, 228-241.

Harmelin, J.-G., Bachet, F., \& Garcia, F. (1995). Mediterranean marine reserves: Fish indices as tests of protection efficiency. PSZN I: Marine Ecology, 16, 230-250.

Harmelin, J.-G., \& Marinopolous, J. (1993). Recensement de la population de corbs (Sciaena umbra, Linneaus 1758: Pisces) du Parc national de Port-Cros (Méditerránée, France) par inventaires visuels. Scientific Reports of the Port-Cros Nationall Park, France, 15, 265-275.

Harmelin-Vivien, M. L., García-Charton, J. A., BayleSempere, J. T., Charbonnel, E., Le Diréach, L., Ody, D., et al. (2007). Importance of marine reserves for the population dynamics of groupers (Epinephelinae) in the western Mediterranean. In Second symposium on Mediterranean Groupers, Nice (pp. 91-93).

Harmelin-Vivien, M. L., Harmelin, J.-G., \& Leboulleux, V. (1995). Microhabitat requirements for settlement of juvenile sparid fishes on Mediterranean rocky shores. Hydrobiologia, 300/301, 309-320. 
Harmelin-Vivien, M. L., Le Diréach, L., Bayle-Sempere, J. T., Charbonnel, E., García-Charton, J. A., Ody, D., et al. (2008). Gradients of abundance and biomass across reserve boundaries in six Mediterranean marine protected areas: Evidence of fish spillover? Biological Conservation, 141, 1829-1839.

Hereu, B. (2004). The role of trophic interactions between fishes, sea urchins and algae in the northwest Mediterranean rocky infralittoral. Ph.D. Thesis, University of Barcelona (295pp.)

Hereu, B. (2006). Depletion of palatable algae by sea urchins and fishes in a Mediterranean subtidal community. Marine Ecology Progress Series, 313, 95-103.

Hereu, B., Zabala, M., Linares, C., \& Sala, E. (2004). Temporal and spatial variability in settlement of the sea urchin Paracentrotus lividus in the NW Mediterranean. Marine Biology, 144, 1011-1018.

Hereu, B., Zabala, M., Linares, C., \& Sala, E. (2005). The effects of predator abundance and habitat structural complexity on survival of juvenile sea urchins. Marine Biology, 146, 293-299.

Hernández, J. C., Clemente, S., Falcón, J. M., Brito, A., \& Barquín, J. (2005). Valoración de las reservas marinas de Canarias como herramientas de ordenación para el control de las poblaciones del erizo Diadema antillarum (Echinoidea: Diadematidae). Vieraea, 33, 399-418.

Hernández, J. C., Clemente, S., Sangil, C., \& Brito, A. (2007). Actual status of the sea urchin Diadema aff. antillarum populations and macroalgal cover in marine protected areas compared to a highly fished area (Canary Islands-eastern Atlantic Ocean). Aquatic Conservation: Marine and Freshwater Ecosystems, doi:10.1002/aqc. 903.

Hernández, J. C., Clemente, S., Sangil, C., \& Brito, A. (2008). The key role of the sea urchin Diadema aff. antillarum in controlling macroalgae assemblages throughout the Canary Islands (eastern subtropical Atlantic): A spatio-temporal approach. Marine Environmental Research, 66, 259-270.

Hilborn, R. (2004). Ecosystem-based fisheries management: The carrot or the stick? Marine Ecology Progress Series, 274, 275-278.

Hilborn, R., Stokes, K., Maguire, J.-J., Smith, T., Botsford, L. W., Mangel, M., et al. (2004). When can marine reserves improve fisheries management? Ocean, and Coastal Management, 47, 197-205.

Hughes, T. P., Baird, A. H., Bellwood, D. R., Card, M., Connolly, S. R., Folke, C., et al. (2003). Climate change, human impacts, and the resilience of coral reefs. Science, 301, 929-933.

Hughes, T. P., Bellwood, D. R., Folke, C., McCook, L. J., \& Pandolfi, J. M. (2007). No-take areas, herbivory and coral reef resilience. Trends in Ecology and Evolution, 22, 1-3.

Hughes, T. P., Bellwood, D. R., Folke, C., Steneck, R. S., \& Wilson, J. (2005). New paradigms for supporting the resilience of marine ecosystems. Trends in Ecology and Evolution, 20, 380-386.

Jackson, J. B. C. (2008). Ecological extinction and evolution in the brave new ocean. Proceedings of the National Academy of Sciences, 105, 11458-11465.
Jackson, J. B. C., Kirby, M. X., Berger, W. H., Bjorndal, K. A., Botsford, L. W., Bourque, B. J., et al. (2001). Historical overfishing and the recent collapse of coastal ecosystems. Science, 293, 629-638.

Jackson, J. B. C., \& Sala, E. (2001). Unnatural oceans. Scientia Marina, 65, 273-281.

Jacquet, S. (1999). Etude de "l'effet réserve » de la Réserve Naturelle Marine de Cerbère-Banyuls à l'aide de l'espèce indicatrice: Mytilus galloprovincialis. Diplôme d'ingénieur ISIM (Montpellier) (45pp. +3 annexes).

Jennings, S. (2004). The ecosystem approach to fishery management: A significant step towards sustainable use of the marine environment? Marine Ecology Progress Series, 274, 279-282.

Jones, G. P., Cole, R. C., \& Battershill, C. N. (1992). Marine reserves: Do they work? In C. N. Battershill, D. R. Schiel, G. P. Jones, R. G. Creese, A. B. MacDiarmid (Eds.), Proceedings of the second international temperate reef symposium, 7-10 January 1992, Auckland, New Zealand (pp. 29-45). NIWA Marine.

Jørgensen, C., Enberg, K., Dunlop, E. S., Arlinghaus, R., Boukal, D., Brander, K., et al. (2007). Managing evolving fish stocks. Science, 318, 1247-1248.

Kaiser, M. J., Clarke, K. R., Hinz, H., Austen, M. C. V., Somerfield, P. J., \& Karakassis, I. (2006). Global analysis of response and recovery of benthic biota to fishing. Marine Ecology Progress Series, 311, 1-14.

Kaunda-Arara, B., \& Rose, G. A. (2004). Effects of marine reef National Parks on fishery CPUE in coastal Kenya. Biological Conservation, 118, 1-13.

Knowlton, N. (2004). Multiple "stable" states and the conservation of marine ecosystems. Progress in Oceanography, 60, 387-396.

Knowlton, N., \& Jackson, J. B. C. (2008). Shifting baselines, local impacts, and global change on coral reefs. PLOS Biology, 6, 215-220.

Kuparinen, A., \& Merilä, J. (2007). Detecting and managing fisheries-induced evolution. Trends in Ecology and Evolution, 22, 652-659.

La Mesa, G., Louisy, P., \& Vacchi, M. (2002). Assessment of microhabitat preferences in juvenile dusky grouper (Epinephelus marginatus) by visual sampling. Marine Biology, 140, 175-185.

La Mesa, G., \& Vacchi, M. (1999). An analysis of the coastal fish assemblage of the Ustica Island Marine Reserve. PSZN I: Marine Ecology, 20, 147-165.

Laborel-Deguen, F., \& Laborel, J. (1991). Statut de Patella ferruginea Gmelin en Méditerranée. In C. F. Boudouresque, M. Avon, \& V. Gravez (Eds.), Les Espèces Marines à Protéger en Méditerranée (pp. 91-103). France: GIS Posidonie Publ.

Laurel, B. J., \& Bradbury, I. R. (2006). "Big” concerns with high latitude marine protected areas (MPAs): Trends in connectivity and MPA size. Canadian Journal of Fisheries and Aquatic Sciences, 63, 2603-2607.

Lecchini, D., Lenfant, P., \& Planes, S. (2002). Variation in abundance and population dynamics of the sea urchin Paracentrotus lividus on the Catalan coast (northwestern Mediterranean Sea) in relation to habitat and marine reserve. Vie Milieu, 52, 111-118. 
Le Diréach, L., \& Francour, P. (1998). Recrutement de Diplodus annularis (Sparidae) dans les herbiers de posidonie de la Réserve Naturelle de Scandola (Corse). Travaux Scientifiques du Parc Naturel Régional de Corse (France), 57, 42-75.

Ledlie, M. H., Graham, N. A. J., Bythell, J. C., Wilson, S. K., Jennings, S., Polunin, N. V. C., et al. (2007). Phase shifts and the role of herbivory in the resilience of coral reefs. Coral Reefs, 26, 641-653.

Lembo, G., Spedicato, M. T., Okland, F., Carbonara, P., Fleming, I. A., McKinley, R. S., et al. (2002). A wireless communication system for determining site fidelity of juvenile dusky groupers Epinephelus marginatus (Lowe, 1834) using coded acoustic transmitters. Hydrobiologia, 483, 249-257.

Lenfant, P. (2003). Demographic and genetic structures of white sea bream populations (Diplodus sargus, Linneaeus, 1758) inside and outside a Mediterranean marine reserve. Comptes Rendues Biologies, 326, 751-760.

Leslie, H., Ruckelshaus, M., Ball, I. R., Andelman, S., \& Possingham, H. P. (2003). Using siting algorithms in the design of marine reserve networks. Ecological Applications, 13, 185-198.

Lewison, R. L., Crowder, L. B., Read, A. J., \& Freeman, S. A. (2004). Understanding impacts of fisheries bycatch on marine megafauna. Trends in Ecology and Evolution, 19, 598-604.

Lloret, J., \& Planes, S. (2003). Condition, feeding and reproductive potential of white seabream Diplodus sargus as indicators of habitat quality and the effect of reserve protection in the northwestern Mediterranean. Marine Ecology Progress Series, 248, 197-208.

Longhurst, A. (2006). The sustainability myth. Fisheries Research, 81, 107-112.

Longhurst, A. (2007). Doubt and certainty in fishery science: Are we really headed for a global collapse of stocks? Fisheries Research, 86, 1-5.

Lotze, H. K., Lenihan, H. S., Bourque, B. J., Bradbury, R. H., Cooke, R. G., Kay, M. C., et al. (2006). Depletion, degradation, and recovery potential of estuaries and coastal seas. Science, 312, 1806-1809.

Louisy, P., \& Culioli, J. M. (1999). Synthèse des observations sur l'activité reproductrice du mérou brun, Epinephelus marginatus (Lowe, 1834) en Méditerranée nord-occidentale. Marine Life, 9, 47-57.

Lubchenco, J., Palumbi, S. R., Gaines, S. D., \& Andelman, S. (2003). Plugging a hole in the ocean: The emerging science of marine reserves. Ecological Applications, 13, S3-S7.

Mace, P. M. (2004). In defence of fisheries scientists, single-species models and other scapegoats: Confronting the real problems. Marine Ecology Progress Series, 274, 285-291.

Macpherson, E. (1998). Ontogenetic shifts in habitat use and aggregation in juvenile sparid fishes. Journal of Experimental Marine Biology and Ecology, 220, 127-150.

Macpherson, E., Biagi, F., Francour, P., García-Rubies, A., Harmelin, J.-G., Harmelin-Vivien, M. L., et al. (1997).
Mortality of juvenile fishes of the genus Diplodus in protected and unprotected areas in the western Mediterranean Sea. Marine Ecology Progress Series, 160, 135-147.

Macpherson, E., García-Rubies, A., \& Gordoa, A. (2000). Direct estimation of natural mortality rates for littoral marine fishes using populational data from a marine reserve. Marine Biology, 137, 1067-1076.

Macpherson, E., Gordoa, A., \& García-Rubies, A. (2002). Biomass size spectra in littoral fishes in protected and unprotected areas in the NW Mediterranean. Estuarine, Coastal and Shelf Science, 55, 777-788.

Maiorano, L., Bartolino, V., Colloca, F., Abella, A., Belluscio, A., Carpentieri, P., et al. (in press). Systematic conservation planning in the Mediterranean: a flexible tool for the identification of no-take marine protected areas. ICES Journal of Marine Science.

Martínez, M. L., Intralawan, A., Vázquez, G., \& PérezMaqueo, O. (2007). The coast of our world: Ecological, economic and social importance. Ecological Economics, 63, 254-272.

McCann, K. S. (2000). The diversity-stability debate. Nature, 405, 228-233.

McClanahan, T. R., Graham, N. A. J., Calnan, J. M., \& MacNeil, M. A. (2007). Toward pristine biomass: Reef fish recovery in coral reef marine protected areas in Kenya. Ecological Applications, 17, 1055-1067.

McClanahan, T. R., Hicks, C. C., \& Darling, E. S. (2008). Malthusian overfishing and efforts to overcome it on Kenyan coral reefs. Ecological Applications, 18, 1516-1529.

McClanahan, T. R., Kamukuru, A. T., Muthiga, N. A., Yebio, M. G., \& Obura, D. (1996). Effect of sea urchin reductions on algae, coral, and fish populations. Conservation Biology, 10, 136-154.

McClanahan, T. R., \& Sala, E. (1997). A Mediterranean rocky-bottom ecosystem fisheries model. Ecological Modelling, 104, 145-164.

McGinnis, M. V. (2006). Negotiating ecology: Marine bioregions and the destruction of the Southern California Bight. Futures, 38, 382-405.

Meier, C. (2003). Comparaison inter-annuelles et intersites des effectifs de Patella ferruginea dans la RNBB. IUP Génie de l'Environnement. Université de Corse.

Mérigot, B., Letourneur, Y., \& Lecomte-Finiger, R. (2007). Characterization of local populations of the common sole Solea solea (Pisces, Soleidae) in the NW Mediterranean through otolith morphometrics and shape analysis. Marine Biology, 151, 997-1008.

Micheli, F., Benedetti-Cecchi, L., Gambaccini, S., Bertocci, I., Borsini, C., Osio, G. C., et al. (2005). Cascading human impacts, marine protected areas, and the structure of Mediterranean reef assemblages. Ecological Monographs, 75, 81-102.

Micheli, F., \& Halpern, B. S. (2005). Low functional redundancy in coastal marine assemblages. Ecology Letters, 8, 391-400.

Micheli, F., Halpern, B. S., Botsford, L. W., \& Warner, R. R. (2004). Trajectories and correlates of community 
change in no-take marine reserves. Ecological Applications, 14, 1709-1723.

Milazzo, M., Anastasi, I., \& Willis, T. J. (2006). Recreational fish feeding affects coastal fish behavior and increases frequency of predation on damselfish (Chromis chromis) nests. Marine Ecology Progress Series, 310, 165-172.

Milazzo, M., Badalamenti, F., Ceccherelli, G., \& Chemello, R. (2004a). Boat anchoring on Posidonia oceanica beds in a marine protected area (Italy, western Mediterranean): Effect of anchor types in different anchoring stages. Journal of Experimental Marine Biology and Ecology, 299, 51-62.

Milazzo, M., Badalamenti, F., Riggio, S., \& Chemello, R. (2004b). Patterns of algal recovery and small-scale effects of canopy removal as a result of human trampling on a Mediterranean rocky shallow community. Biological Conservation, 117, 191-202.

Milazzo, M., Badalamenti, F., Vega-Fernandez, T., \& Chemello, R. (2005). Effects of fish feeding by snorkellers on the density and size distribution of fishes in a Mediterranean marine protected area. Marine Biology, 146, 1213-1222.

Milazzo, M., Chemello, R., Badalamenti, F., Camarda, R., \& Riggio, S. (2002a). The impact of human recreational activities in marine protected areas: What lessons should be learnt in the Mediterranean Sea? PSZN I: Marine Ecology, 23, 280-290.

Milazzo, M., Chemello, R., Badalamenti, F., \& Riggio, S. (2002b). Short term effect of human trampling on the upper infralittoral macroalgae of Ustica Island MPA (Western Mediterranean, Italy). Journal of Marine Biological Association of United Kingdom, 82, 745-748.

Misund, O. A., \& Skjoldal, H. R. (2005). Implementing the ecosystem approach: Experiences from the North Sea, ICES, and the Institute of Marine Research, Norway. Marine Ecology Progress Series, 300, 260-265.

Molloy, P. P., Reynolds, J. D., Gage, M. J. G., Mosqueira, I., \& Côté, I. M. (2008). Links between sex change and fish densities in marine protected areas. Biological Conservation, 141, 187-197.

Morato, T., Afonso, P., Lourinho, P., Nash, R. D. M., \& Santos, R. S. (2003). Reproductive biology and recruitment of the white sea bream in the Azores. Journal of Fish Biology, 63, 59-72.

Mouillot, D., Culioli, J.-G., Pelletier, D., \& Tomasini, J. A. (2008). Do we protect biological originality in protected areas? A new index and an application to the Bonifacio Strait Natural Reserve. Biological Conservation, 141, 1569-1580.

Mumby, P. J., Dahlgren, C. P., Harborne, A. R., Kappel, C. V., Micheli, F., Brumbaugh, D. R., et al. (2006). Fishing, trophic cascades, and the process of grazing on coral reefs. Science, 311, 98-101.

Mumby, P. J., Harborne, A. R., Williams, J., Kappel, C. V., Brumbaugh, D. R., Micheli, F., et al. (2007). Trophic cascades facilitate coral recruitment in a marine reserve. Proceedings of the National Academy of Sciences, 104, 8362-8367.
Myers, R. A., \& Worm, B. (2003). Rapid worldwide depletion of predatory fish communities. Nature, 423, 280-283.

Ojeda-Martínez, C., Bayle-Sempere, J. T., SánchezJerez, P., Forcada, A., \& Valle, C. (2007). Detecting conservation benefits in spatially protected fish populations with meta-analysis of long-term monitoring data. Marine Biology, 151, 1153-1161.

Pais, A., Chessa, L. A., Serra, S., Ruiu, A., Meloni, G., \& Donno, Y. (2007). The impact of commercial and recreational harvesting for Paracentrotus lividus on shallow rocky reef sea urchin communities in northwestern Sardinia, Italy. Estuarine, Coastal and Shelf Science, 73, 589-597.

Palmeri, A. (2004). Struttura e composizione dei popolamenti ittici di due aree marine protette siciliane. Master Thesis, University of Palermo.

Palumbi, S. R. (2001). The ecology of marine protected areas. In M. D. Bertness, S. D. Gaines, \& M. E. Hay (Eds.), Marine community ecology (pp. 509-530). Sinauer Associates, Inc. Publ.

Palumbi, S. R. (2003). Population genetics, demographic connectivity, and the design of marine reserve. Ecological Applications, 13, S146-S158.

Palumbi, S. R., Gaines, S. D., Leslie, H., \& Warner, R. R. (2003). New wave: High-tech tools to help marine reserve research. Frontiers in Ecology and Environment, 1, 73-79.

Parnell, P. E., Dayton, P. K., Lennert-Cody, C. E., Rasmussen, L. L., \& Leichter, J. J. (2006). Marine reserve design: Optimal size, habitats, species affinities, diversity, and ocean microclimate. Ecological Applications, 16, 945-962.

Pauly, D. (1995). Anecdotes and the shifting baseline syndrome of fisheries. Trends in Ecology and Evolution, $10,430$.

Pauly, D. (2005). Global trends in world fisheries: Impacts on marine ecosystems and food security. Philosophical Transactions of the Royal Society B, 360, 5-12.

Pauly, D., Christensen, V., Guénette, S., Pitcher, T. J., Sumaila, U. R., Walters, C. J., et al. (2002). Towards sustainability in world fisheries. Nature, 418, 689-695.

Pelletier, D., Claudet, J., Ferraris, J., Benedetti-Cecchi, L., \& García-Charton, J. A. (2008). Models and indicators for assessing conservation and fisheriesrelated effects of marine protected areas. Canadian Journal of Fisheries and Aquatic Sciences, 65, 765-779.

Pelletier, D., García-Charton, J. A., Ferraris, J., David, G., Thébaud, O., Letourneur, Y., et al. (2005). Designing indicators for evaluating the impact of Marine Protected Areas on coral reef ecosystems: A multidisciplinary standpoint. Aquatic Living Resources, 18, 15-33.

Pérez-Ruzafa, A., González-Wangüemert, M., Lenfant, P., Marcos, C., \& García-Charton, J. A. (2006). Effects of fishing protectionn on the genetic structure of fish populations. Biological Conservation, 129, 244-255.

Pérez-Ruzafa, A., Martín, E., Zamarro, J.M., Stobart, B., Harmelin-Vivien, M., Planes, S., et al. (2008). Modelling 
spatial and temporal scales for spillover and biomass exportation from MPAs and their potential for fisheries enhancement. Journal for Nature Conservation, this issue, doi:10.1016/j.jnc.2008.09.003.

Pinnegar, J. K., \& Engelhard, G. H. (2008). The 'shifting baseline' phenomenon: A global perspective. Reviews on Fish Biology and Fisheries, 18, 1-16.

Pinnegar, J. K., Polunin, N. V. C., Francour, P., Badalamenti, F., Chemello, R., Harmelin-Vivien, M.-L., et al. (2000). Trophic cascades in benthic marine ecosystems: Lessons for fisheries and protected-area management. Environmental Conservation, 27, 179-200.

Pipitone, C., Badalamenti, F., D’Anna, G., \& Patti, B. (2000). Fish biomass increase after a four-year trawl ban in the Gulf of Castellammare (NW Sicily, Mediterranean Sea). Fisheries Research, 48, 23-30.

Plan Development Team (1990). The potential of marine fishery reserves for reef fish management in the US Southern Atlantic. NOAA.

Planes, S., Galzin, R., García-Rubies, A., Goñi, R., Harmelin, J.-G., Le Diréach, L., et al. (2000). Effects of marine protected areas on recruitment processes with special reference to Mediterranean littoral ecosystems. Environmental Conservation, 27, 126-143.

Planes, S., García-Charton, J. A., Marcos, C., \& PérezRuzafa, A. (2008). Ecological effects of AtlantoMediterranean marine protected areas in the European Union. EMPAFISH Project, Booklet no 1. Editum (158pp.)

Planes, S., Jouvenel, J. Y., \& Lenfant, P. (1998). Density dependence in post-recruitment processes of juvenile sparids in the littoral of the Mediterranean Sea. Oikos, 83, 293-300.

Pomeroy, R. S., Watson, L. M., Parks, J. E., \& Cid, G. A. (2005). How is your MPA doing? A methodology for evaluating the management effectiveness of marine protected areas. Ocean and Coastal Management, 48, 485-502.

Porcher, M. (1984). Impact des mouillages forains sur les herbiers à Posidonia oceanica. In C. F. Boudouresque, A. Jeudy de Grissac, \& J. Olivier (Eds.), International Workshop on Posidonia oceanica beds, Vol. 1 (pp. 145-148). France: GIS Posidonie Publ.

RAC/SPA (2003). Strategic Action Plan for the conservation of biological diversity (SAP BIO) in the Mediterranean region. Tunis: UNEP-MAP, Tunis (104pp.).

Rakitin, A., \& Kramer, D. L. (1996). Effect of marine reserve on the distribution of coral reef fishes in Barbados. Marine Ecology Progress Series, 131, 97-113.

Raventós, N., \& Macpherson, E. (2005). Environmental influences on temporal patterns of settlement in two littoral labrid fishes in the Mediterranean Sea. Estuarine, Coastal and Shelf Science, 63, 479-487.

Reñones, O., Goñi, R., Pozo, M., Deuderó, S., \& Moranta, J. (1999). Effects of protection on the demographic structure and abundance of Epinephelus marginatus (Lowe, 1834). Evidence from Cabrera Archipelago National Park (West-central Mediterranean). Marine Life, 9, 45-53.
Reñones, O., Quetglas, A., \& Goñi, R. (2001). Effects of fishing restrictions on the abundance, size structure and mortality rate of a western Mediterranean population of Scorpaena scrofa (Linnaeus, 1758). Rapports de la Commission Internationale pour l'Exploration Scientifique de la Mer Méditerranée, 36, 316.

Robert, P. (1983). Dégradation de l'herbier de Posidonies dans la zone de mouillage organisé de la Baie de PortCros. Travaux Scientifiques du Parc national de PortCros, France, 7, 25-34.

Roberts, C. M., Bohnsack, J. A., Gell, F., Hawkins, J. P., \& Goodridge, R. (2001). Effects of marine reserves on adjacent fisheries. Science, 294, 1920-1923.

Roberts, C. M., Hawkins, J. P., \& Gell, F. (2005). The role of marine reserves in achieving sustainable fisheries. Philosophical Transactions of the Royal Society B, 360, 123-132.

Roberts, C. M., \& Polunin, N. V. C. (1991). Are marine reserves effective in management of reef fisheries? Reviews in Fish Biology and Fisheries, 1, 65-91.

Roberts, C. M., \& Polunin, N. V. C. (1993). Marine reserves: Simple solutions to managing complex fisheries? Ambio, 22, 363-368.

Rodrigues, A. S. L., Andelman, S. J., Bakarr, M. I., Boitani, L., Brooks, T. M., M.C.R., et al. (2004). Effectiveness of the global protected area network in representing species diversity. Nature, 428, 640-643.

Rowley, R. J. (1994). Marine reserves in fisheries management. Aquatic Conservation: Marine and Freshwater Ecosystems, 4, 233-254.

Russ, G. R. (2002). Yet another review of marine reserves as reef fishery management tools. In P. F. Sale (Ed.), Coral reef fishes: Dynamics and diversity in a complex ecosystem (pp. 421-443). New York: Academic Press.

Russ, G. R., \& Alcala, A. C. (1996). Do marine reserves export adult fish biomass? Evidence from Apo island, Central Philippines. Marine Ecology Progress Series, 132, 1-9.

Russ, G. R., \& Alcala, A. C. (2004). Marine reserves: Longterm protection is required for full recovery of predatory fish populations. Oecologia, 138, 622-627.

Russ, G. R., Stockwell, B., \& Alcala, A. C. (2005). Inferring versus measuring rates of recovery in no-take marine reserves. Marine Ecology Progress Series, 292, $1-12$.

Sala, E. (2004). The past and present topology and structure of Mediterranean subtidal rocky-shore food webs. Ecosystems, 7, 333-340.

Sala, E., Aburto-Oropeza, O., Paredes, G., Parra, I., Barrera, J. C., \& Dayton, P. K. (2002). A general model for designing networks of marine reserves. Science, 298, 1991-1993.

Sala, E., Boudouresque, C. F., \& Harmelin-Vivien, M. (1998). Fishing, trophic cascades, and the structure of algal assemblages: Evaluation of an old but untested paradigm. Oikos, 82, 425-439.

Sala, E., Garrabou, J., \& Zabala, M. (1996). Effects of diver frequentation on Mediterranean sublittoral populations of the bryozoan Pentapora fascialis. Marine Biology, 126, 451-459. 
Sala, E., \& Knowlton, N. (2006). Global marine biodiversity trends. Annual Review Environmental Resources, 31, 93-122.

Sale, P. F., Cowen, R. K., Danilowicz, B. S., Jones, G. P., Kritzer, J. P., Lindeman, K. C., et al. (2005). Critical science gaps impede use of no-take fishery reserves. Trends in Ecology and Evolution, 20, 74-80.

Salm, RV., Clark, J. R., \& Siirila, E. (2000). Marine and coastal protected areas: $A$ guide for planners and managers. Washington, DC: IUCN.

Sánchez-Lizaso, J. L., Goñi, R., Reñones, O., GarcíaCharton, J. A., Galzin, R., Bayle-Sempere, J. T., et al. (2000). Density dependence in marine protected populations: A review. Environmental Conservation, 27, 144-158.

Sandin, S. A., Smith, J. E., DeMartini, E. E., Dinsdale, E. A., Donner, S. D., Friedlander, A. M., et al. (2008). Baselines and degradation of coral reefs in the Northern Line Islands. PLOS One, 3, 1-11.

Sasal, P. (2003). Experimental test of the influence of the size of shoals and density of fish on parasite infections. Coral Reefs, 22, 241-246.

Sasal, P., Faliex, E., \& Morand, S. (1996). Parasitism of Gobius bucchichii Steindachner, 1870 (Teleostei, Gobiidae) in protected and unprotected marine environment. Journal of Wild Disease, 32, 607-613.

Sasal, P., Morand, S., \& Guégan, J.-M. (1997). Determinants of parasite species richness in Mediterranean marine fishes. Marine Ecology Progress Series, 149, 61-71.

Schrope, M. (2001). Biologists urge US to build marine reserves. Nature, 409, 971.

Scotti, G., \& Chemello, R. (2000). I Molluschi marini degni di protezione: Stato delle conoscenze e forme di tutela. Bollettino Malacologico, 36, 61-70.

Sherman, K., Sissenwine, M., Christensen, V., Duda, A., Hempel, G., Ibe, C., et al. (2005). A global movement toward an ecosystem approach to management of marine resources. Marine Ecology Progress Series, 300, 275-279.

Sissenwine, M., \& Murawski, S. (2004). Moving beyond 'intelligent tinkering': Advancing and Ecosystem Approach to Fisheries. Marine Ecology Progress Series, 274, 291-295.

Smith, A. D. M., Fulton, E. J., Hobday, A. J., Smith, D. C., \& Shoulder, P. (2007). Scientific tools to support the practical implementation of ecosystem-based fisheries management. ICES Journal of Marine Science, 64, 633-639.

Stelzenmüller, V., Maynou, F., \& Martín, P. (2007). Spatial assessment of benefits of a coastal Mediterranean marine protected area. Biological Conservation, 136, 571-583.

Stevenson, C., Katz, L. S., Micheli, F., Block, B., Heiman, K. W., Perle, C., et al. (2007). High apex predator biomass on remote Pacific islands. Coral Reefs, 26, 47-51.

Stobart, B., García-Charton, J. A., Espejo, C., Rochel, E., Goñi, R., Reñones, O., et al. (2007). A baited underwater video technique to assess shallow water
Mediterranean fish assemblages: Methodological evaluation. Journal of Experimental Marine Biology and Ecology, 345, 158-174.

Swain, D. P., Sinclair, A. F., \& Hanson, J. M. (2007). Evolutionary response to size-selective mortality in an exploited fish population. Proceedings of the Royal Society B, 274, 1015-1022.

Tomás, F., Romero, J., \& Turón, X. (2004). Settlement and recruitment of the sea urchin Paracentrotus lividus in two contrasting habitats in the Mediterranean. Marine Ecology Progress Series, 282, 173-184.

Tudela, S. (2000). Ecosystem effects of fishing in the Mediterranean: An analysis of the major threats of fishing gear and practices to biodiversity and marine habitats. Rome: FAO (45pp.).

Tunesi, L., Molinari, A., \& Salvati, E. (2006). Fish assemblage of the marine protected area of Cinque Terre (NW Mediterranean Sea): First characterization and assessment by visual census. Chemistry and Ecology, 22, 245-253.

Tuya, F., Ortega-Borges, L., Del Rosario-Pinilla, A. B., \& Haroun, R. J. (2006). Spatiotemporal variability in a key herbivore, the long-spined black sea urchin (Diadema antillarum, Echinodermata: Echinoidea) in the Canary Islands. Journal of the Marine Biological Association of the United Kingdom, 86, 791-797.

Vaselli, S., Bertocci, I., Maggi, E., \& Benedetti-Cecchi, L. (2008). Effects of mean intensity and temporal variance of sediment scouring events on assemblages of rocky shores. Marine Ecology Progress Series, 364, 57-66.

Verlaque, M. (1987). Relations entre Paracentrotus lividus (Lamarck) et le phytobenthos de Mediterranée occidentale. In C. F. Boudouresque (Ed.), Colloque international sur Paracentrotus lividus et les oursins comestibles (pp. 5-36). Marseille: GIS Posidonie.

Vigliola, L., Harmelin-Vivien, M. L., Biagi, F., Galzin, R., García-Rubies, A., Harmelin, J.-G., et al. (1998). Spatial and temporal patterns of settlement among sparid fishes of the genus Diplodus in the northwestern Mediterranean. Marine Ecology Progress Series, 168, 45-56.

Walsh, M. R., Munch, S. B., Chiba, S., \& Conover, D. 0. (2006). Maladaptive changes in multiple traits caused by fishing: Impediments to population recovery. Ecology Letters, 9, 142-148.

Ward, T. J., Heinemann, D., \& Evans, N. (2001). The role of marine reserves as fisheries management tools: $A$ review of concepts, evidence and international experience. Canberra, Australia: Bureau of Rural Sciences (192pp.).

Wood, L. J., Fish, L., Laughren, J., \& Pauly, D. (2008). Assessing progress towards global marine protection targets: Shortfalls in information and action. Oryx, 42, 340-351.

Worm, B., Barbier, E. B., Beaumont, N., Duffy, J. E., Folke, C., Halpern, B. S., et al. (2006). Impacts of biodiversity loss on ocean ecosystem services. Science, 314, 787-790.

Zabala, M., Garcia-Rubies, A., Louisy, P., \& Sala, E. (1997). Spawning behaviour of the Mediterranean 
dusky grouper Epinephelus marginatus (Lowe, 1834) (Pisces, Serranidae) in the Medes Islands Marine Reserve (NW Mediterranean, Spain). Scientia Marina, 61, 65-77.

Zeller, D., \& Russ, G. R. (1998). Marine reserves: Patterns of adult movement of the coral trout Plectropomus leopardus (Serranidae). Canadian Journal of Fisheries and Aquatic Sciences, 55, 917-924.

Ziegler, P. E., Lyle, J. M., Haddon, M., \& Ewing, G. P. (2007). Rapid changes in life-history characteristics of a long-lived temperate reef fish. Marine and Freshwater Research, 58, 1096-1107. 